\title{
СМЕРТНОСТЬ В РОССИИ: НЕСОСТОЯВШАЯСЯ ВТОРАЯ ЭПИДЕМИОЛОГИЧЕСКАЯ РЕВОЛЮЦИЯ*
}

\author{
АНАТОЛИЙ ВИШНЕВСКИЙ
}

\begin{abstract}
Рассматриваются различные подходы к концептуальному осмыслению современного этапа снижения смертности, когда на первый план вышла борьба с неинфекционными причинами смерти («новые этапьы» эпидемиологического перехода, «вторая эпидемиологическая революция», «санитарный переход»). На этом этапе, продолжающемся уже не менее полувека, в большинстве развитых стран произошли революиионные изменения, выразившиеся в резком расширении контроля над неинфекционными причинами смерти, в частности, над заболеваниями системы кровообращения, новообразованиями, другими неинфекционными болезнями, внешними причинами. Следствием этих изменений стало быстрое оттеснение смертей от этих причин к стариим возрастам, увеличение среднего возраста смерти от них, в конечном счете, значительный рост ожидаемой продолжительности жизни. Между тем Россия, в основном, осталась в стороне от этих изменений и не смогла обеспечить должного роста контроля над неинфекционными причинами смерти. Возрастное распределение смертей от крупных классов причин в России за последние полвека почти не изменилось, что обусловило стагнацию ожидаемой продолжительности жизни и нарастающее отставание по этому показателю от большинства развитых стран. «Вторая эпидемиологическая революичя» в России все ещуе остается делом будущего.
\end{abstract}

Ключевые слова: эпидемиологический переход, эпидемиологическая револючия, вторая эпидемиологическая револючия, санитарный переход, причины смерти, смертность от неинфекичинных болезней.

\section{ЭПИДЕМИОЛОГИЧЕСКИЙ ПЕРЕХОД, ЭПИДЕМИОЛОГИЧЕСКАЯ РЕВОЛЮЦИЯ, САНИТАРНЫЙ ПЕРЕХОД}

Концепция эпидемиологического перехода была сформулирована американским демографом Абделем Омраном в 1971 г. в статье «Эпидемиологический переход: теория эпидемиологии демографических изменений» [Omran 1971]1.

\footnotetext{
АНАТОЛИЙ ГРИГОРЬЕВИЧ ВИШНЕВСКИЙ, ИНСТИТУТ ДЕМОГРАФИИ НАЦИОНАЛЬНОГО ИССЛЕДОВАТЕЛЬСКОГО УНИВЕРСИТЕТА «ВЫСШАЯ ШКОЛА ЭКОНОМИКИ». РОССИЯ. E-mail: avishnevsky@hse.ru СТАТЬя ПОСТУПИЛА в РЕДАКЦИЮ в АВГУСТЕ 2014 Г.

* В СТАТЬЕ ИСПОЛЬЗОВАНЫ РЕЗУЛЬТАТЫ ИССЛЕДОВАНИЙ, ВЫПОЛНЯВШИХСЯ В РАМКАХ ПРОГРАММЫ ФУНДАМЕНТАЛЬНЫХ ИССЛЕДОВАНИЙ НИУ ВШЭ в 2013-2014 ГГ.
}

\footnotetext{
1 Имеется русский перевод под неточным названием «Эпидемиологический аспект теории естественного движения населения» [Омран 1977].
} 
Термином «эпидемиология» в его привычном значении обозначается наука, изучающая закономерности возникновения и распространения болезней. Этот смысл восходит, вероятно, еще к Гиппократу и его учению об эпидемиях и относится к области медицины. В рамках самой медицины его значение менялось, получая все более расширительное толкование. Поначалу речь шла только об инфекционных болезнях, но затем стали говорить и об эпидемиологии неинфекционных заболеваний, эпидемиологии травматизма. Этот термин употребляется и за пределами медицины, например, говорят об эпидемиологии преступлений. Такое более редкое словоупотребление не противоречит

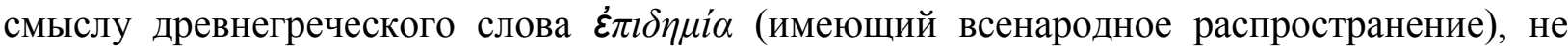
относящемуся непосредственного к медицине.

Омран также трактовал термин «эпидемиологический» в расширительном смысле как указывающий на сущность любых массовых явлений и полагал, что «многие эпидемиологические методы, применение которых до сих пор ограничивалось рассмотрением особенностей здоровья и заболеваемости, могут быть с успехом применены и к исследованию других массовых явлений» [Omran 1971: 509].

Согласно концепции Омрана, эпидемиологический переход - это исторический сдвиг от эпохи, когда смертность в решающей степени зависела от эпидемий и голода, а средняя продолжительность жизни людей колебалась в пределах от 20 до 40 лет, через промежуточную эпоху, когда факторы кризисной смертности, прежде всего эпидемии, утрачивают свою прежнюю роль, смертность снижается, а продолжительность жизни повышается примерно до 50 лет, к эпохе болезней, обусловленных старением организма (дегенеративных болезней) или человеческой деятельностью (degenerative and man-made diseases) [Omran 1971: 516], когда «ожидаемая продолжительность жизни достигает небывалого уровня 70 лет и выше» [Omran 1971: Table 4].

На этой последней стадии «по мере того, как начинают преобладать дегенеративные и хронические заболевания, растут количество психических заболеваний, наркомания, число несчастных случаев, опасность радиации и других явлений, связанных с неблагополучным состоянием окружающей среды» [Omran 1971: 516].

Таким образом, в концепции Омрана уже содержится указание, на борьбе с какими причинами смерти необходимо сосредоточить усилия после того, как инфекционные заболевания - главный источник высокой смертности в прошлом - в основном поставлены под контроль. По-видимому, направление размышлений Омрана было подсказано ситуацией, сложившейся в развитых странах в 1960-е годы, когда рост ожидаемой продолжительности жизни в этих странах замедлился и в экспертной среде появилось сознание того, что возможности прежней стратегии борьбы за повышение продолжительности жизни, ориентированной прежде всего на установление контроля над инфекционными заболеваниями, исчерпываются и эта стратегия нуждается в переосмыслении.

Омран был не единственным, кто осознал необходимость выработки новой стратегии борьбы за дальнейшее удлинение человеческой жизни. Почти одновременно с его статьей American Journal of Public Health опубликовал передовую статью под названием «Эпидемиологическая революция», в которой говорилось, что новая эпидемиология 
расширяет понимание своих задач, выходя за пределы ограниченной области инфекционных заболеваний и включая в круг своих интересов все причины болезней, инвалидности и смерти [Editorials 1972: 1440].

В этой статье, автором которой был американский гигиенист Милтон Террис, упор делается, скорее, на революцию в эпидемиологическом мышлении. Но несколько позднее М. Террис, излагая свою концепцию более подробно, четче указывает на произошедшие за последнее столетие объективные изменения в самой структуре заболеваемости благодаря установлению контроля над инфекционными заболеваниями, что составило смысл первой демографической революции и подвело к новой «большой и трудной задаче: ни много ни мало, осуществить вторую эпидемиологическую революцию и спасти буквально миллионы мужчин и женщин от предотвратимых болезней, инвалидности и смерти» [Terris 1976: 1159]. «В ходе первой эпидемиологической революции органы здравоохранения достигли чудес профилактики инфекционных заболеваний... То же самое может быть верно для второй эпидемиологической революции в профилактике неинфекционных заболеваний» [Terris 1976: 1156]. Хотя здесь говорится о заболеваниях, из общего контекста ясно, что Террис имеет в виду все неинфекционные причины, он с самого начала отмечал, что теперь эпидемиолог должен включать в круг своих интересов не только болезни, но и насильственные причины смерти: несчастные случаи, убийства и самоубийства [Editorials 1972: 1440].

Неинфекционные причины болезней и смерти имеют различную природу. Часть из них обусловлена по преимуществу эндогенными факторами, неотделимыми от возрастных изменений человеческого организма, что делает борьбу с такими причинами особенно сложной, а успехи в этой борьбе ограниченными. Главные возможности здесь связаны, видимо, с тем, что эндогенные факторы человеческого долголетия никогда не бывают отделены непроницаемой перегородкой от экзогенных: человек никогда не живет изолированно от природной и социальной среды. Сроки исчерпания данного ему от природы ресурса долголетия не могут не зависеть от условий труда и отдыха, питания, лечения, привычек и т.д. Влияя на эти условия, можно, до известной степени, противостоять старению, преждевременному износу организма, «ремонтировать» его. Но за счет этого можно лишь оттеснить смерть к более поздним возрастам, сама же смертность от эндогенно обусловленных причин, в принципе, неустранима.

Иначе обстоит дело с другой частью неинфекционных причин смерти, которые зависят преимущественно от экзогенных, внешних факторов и обрывают жизнь вполне здоровых людей задолго до того, как оказывается исчерпанной их естественная жизнеспособность. Эти факторы, как и в случае с инфекционными болезнями, могут быть поставлены под контроль. Такой контроль, вероятно, не может быть абсолютным, но в принципе, обусловленная средовыми факторами смертность устранима. Едва ли не основную массу экзогенно обусловленных и потому устранимых смертей составляют смерти от внешних причин.

По разным причинам, возможно в силу медицинской традиции, сложившейся в период успешной борьбы с инфекционными заболеваниями, задачи и успехи второй эпидемиологической революции часто также воспринимаются прежде всего через призму 
борьбы с болезнями. Отмечая несомненные достижения последних десятилетий в снижении смертности, обычно основное внимание обращают на успехи в борьбе с неинфекционными заболеваниями, прежде всего сердечно-сосудистыми. Подчеркивается, что начало снижения смертности от хронических дегенеративных заболеваний во второй половине XX века стало «краеугольным камнем в истории медицины» [De Flora et al. 2005: 896], говорят о кардиоваскулярной революции как о главном эпидемиологическом изменении [Meslé, Vallin 2002: 444], об успехах в борьбе с раком и т.д. О снижении же смертности от внешних причин смерти говорится гораздо меньше.

Между тем снижение рисков, связанных с внешними причинами смерти, - очень важная составляющая второй эпидемиологической революции. Не случайно, рассматривая десять ведущих причин смерти, которые в ходе этой революции необходимо поставить под контроль прежде всего, Террис на одно из первых место - после сердечно-сосудистых и онкологических заболеваний - ставит внешние причины смерти.

«Несчастные случаи - особенно трагичная причина смерти, потому что их жертвами очень часто становятся дети и молодые люди. Сейчас это ведущая причина смерти в возрасте до 35 лет. Для всех возрастов она занимает четвертое по значимости место; если бы им уделялось внимание, соответствующее их значению для здоровья нации, они, несомненно, могли бы быть исключены из списка десяти ведущих причин смерти. Эпидемиологические исследования углубили наше понимание хозяина, агента и окружающей среды в различных видах несчастных случаев и указали на превентивные меры, которые могут и должны быть использованы» [Terris 1976: 1156].

Любопытно, что Террис не ссылается на Омрана, а в демографической литературе, обильно цитирующей Омрана, нет никаких упоминаний о Террисе. Однако оба они, видимо, независимо друг от друга, четко указывали на то, что мир вступил в новую эру эпоху борьбы с неинфекционными причинами смерти, и оба отмечали, что речь идет не только о болезнях, но и о том, что в современных терминах называется «внешними причинами смерти».

Впоследствии особая самостоятельная роль внешних причин смерти была осознана еще лучше, что привело к выделению их в отдельную группу: все причины смерти были подразделены на (i) инфекционные болезни, причины материнской и перинатальной смертности и смертности, обусловленной плохим питанием, (ii) неинфекционные болезни и (iii) внешние причины смерти [Murray, Lopez 1996: 14].

Согласно концепции Омрана, изложенной в его базовой статье 1971 г., эпидемиологический переход заканчивается эрой дегенеративных и рукотворных болезней и причин смерти, что вполне соответствует картине, наблюдаемой сегодня, по крайней мере, в развитых странах. Эта эра и рассматривалась как последний этап эпидемиологического перехода, первые шаги новой эры в странах Западной и Северной Европы Омран датирует в основном второй половиной XIX века (первый этап - это «практически все еще досовременные модели заболеваемости и смертности»; последний снижение детской смертности, которая «в Англии неуклонно падает с конца XIX века» [Omran 1971: 517, 524]). Если попытаться сопоставить его трактовку с трактовкой Терриса, то, видимо, первую эпидемиологическую революцию Терриса можно рассматривать как 
ранний этап этой эры, закончившийся в развитых странах к середине XX века. Согласно Террису, осознание новой ситуации наметилось в 1940-е годы, и, хотя он и в 70-е годы полагал, что «имеющиеся достижения, возможности, равно как стратегия и тактика, необходимые для реализации второй эпидемиологической революции, не только не поняты; они почти не обсуждаются» [Terris 1976: 1155], судя по последующим результатам, в это время новая стратегия борьбы за снижение смертности уже становилась реальностью.

Позднее в литературе стали появляться предложения разных авторов, включая и самого Омрана [Omran 1998], детализировать предложенную им периодизацию, добавив еще несколько стадий или даже в принципе изменить сам подход к их классификации. Предлагают, например, добавить четвертую стадию - «отсроченных дегенеративных заболеваний», поскольку умирать от них будут все позже и позже, а «продолжительность жизни увеличится до восьми десятилетий, а возможно и более» [Olshansky, Ault 1986: 386]. Но поскольку сам Омран изначально говорил о достижении на третьей стадии перехода ожидаемой продолжительности жизни «70 лет и выше» [Omran 1971, Table 4], что не исключает 80 лет и выше, то едва ли это добавление можно считать серьезным основанием для выделения еще одной стадии. А тем более его нет, поскольку в концепции Омрана важны все же не количественные, а качественные характеристики: на третьей стадии определяющими становятся дегенеративные и рукотворные заболевания, и пока в этом смысле ничего не изменилось.

Другие авторы, считая идею простого добавления еще одной фазы к периодизации Омрана «спорной», присоединяются к идее рассматривать эпидемиологический переход как часть более общего «санитарного перехода» [Meslé, Vallin 2002: 444] с тем, чтобы «объединить в более широком представлении о санитарном переходе первую (описанную Омраном) фазу роста продолжительности жизни в основном за счет снижения смертности от инфекционных болезней и вторую фазу, определяющуюся снижением смертности от сердечно-сосудистых заболеваний, и оставить открытой дверь для последующих фаз» [Meslé, Vallin 2002: 444]. Омран возражал против «переименования» концепции, исходя из своего широкого толкования эпидемиологии, которая «содержит в себе возможности научного анализа влияния экономических, социальных, демографических, здравоохраненческих, технологических и экологических изменений на здоровье... Здоровье - зависимая переменная от эпидемиологии, а не наоборот» [Omran 1998: 99].

Впрочем, и авторы идеи «санитарного перехода» не отказываются от представлений об эпидемиологическом переходе, а лишь дополняют их. Санитарный переход, поясняют они, состоит из собственно эпидемиологического перехода, т.е. долговременных изменений в здоровье населения, «включая изменение моделей заболеваемости, инвалидности и смертности», о чем писал Омран, и из перехода в здравоохранении (health care transition), который представляет собой появление моделей социального ответа на эти изменения [Frenk et al. 1991: 23]. Не касаясь сейчас вопроса о несколько иной, чем у Омрана, интерпретации рядом авторов эпидемиологического перехода, трактовке его, в первую очередь, не как ключевого звена общего демографического перехода, а как ключевого события в процессе долговременного снижения смертности, не обязательно всегда связанного с демографическим переходом [Вишневский 2014: 13] (справедливо и то, и 
другое), отметим, что идея санитарного перехода может быть полезна для анализа ситуации со смертностью в России.

Обычно эта ситуация трактуется как проявление незавершенности эпидемиологического перехода [Вишневский, Школьников 1997: 12-15; Демографическая модернизация 2006: 257-259, 382-395; Вишневский 2009: 56-63], обусловленной догоняющим характером советской модернизации, или даже как «обратный эпидемиологический переход» [Семенова 2005]. Но, может быть, правильнее говорить именно о незавершенном санитарном переходе, о ненайденных моделях социального ответа на требования времени, порожденные изменившимися моделями заболеваемости и смертности. Именно осознание этих требований, отразившееся, в частности, в обобщениях Омрана и Терриса на рубеже 1960-х - 1970-х годов, привело к выработке во многих странах (но, к сожалению, не в России) новой стратегии охраны здоровья и жизни, соответствующей новым условиям. Эта стратегия стала практическим ответом на реальные задачи борьбы со смертностью, вышедшие на первый план после того, как были одержаны решающие победы в борьбе с инфекционными болезнями, и, хотя эти болезни еще не полностью исчезли, они утратили свою прежнюю роль. Она и позволила осуществить предсказанную Террисом вторую эпидемиологическую революцию, возможно, еще не завершившуюся.

\section{РЕШЕНЫ ЛИ ЗАДАЧИ ВТОРОЙ ЭПИДЕМИОЛОГИЧЕСКОЙ РЕВОЛЮЦИИ?}

Со времени пионерных обобщений Омрана и Терриса прошло несколько десятилетий, и сейчас можно судить о том, действительно ли наступила предсказанная ими эра и насколько эффективными оказались усилия по установлению контроля над неинфекционными причинами смерти.

В 1960-е годы ситуацию со смертностью как в успешных западноевропейских странах, так и в тогда еще не столь значительно отстававшей от них России, в решающей степени определяла (как определяет и сейчас) «большая четверка» причин смерти: болезни системы кровообращения, новообразования, болезни органов дыхания и внешние причины. В 1970 г. совокупный вклад четырех классов причин в стандартизованный коэффициент смертности от всех причин в странах Западной Европы был близок к 80\% и в последующие годы даже увеличивался, а в России уже тогда достигал 90\% (рисунок 1). 


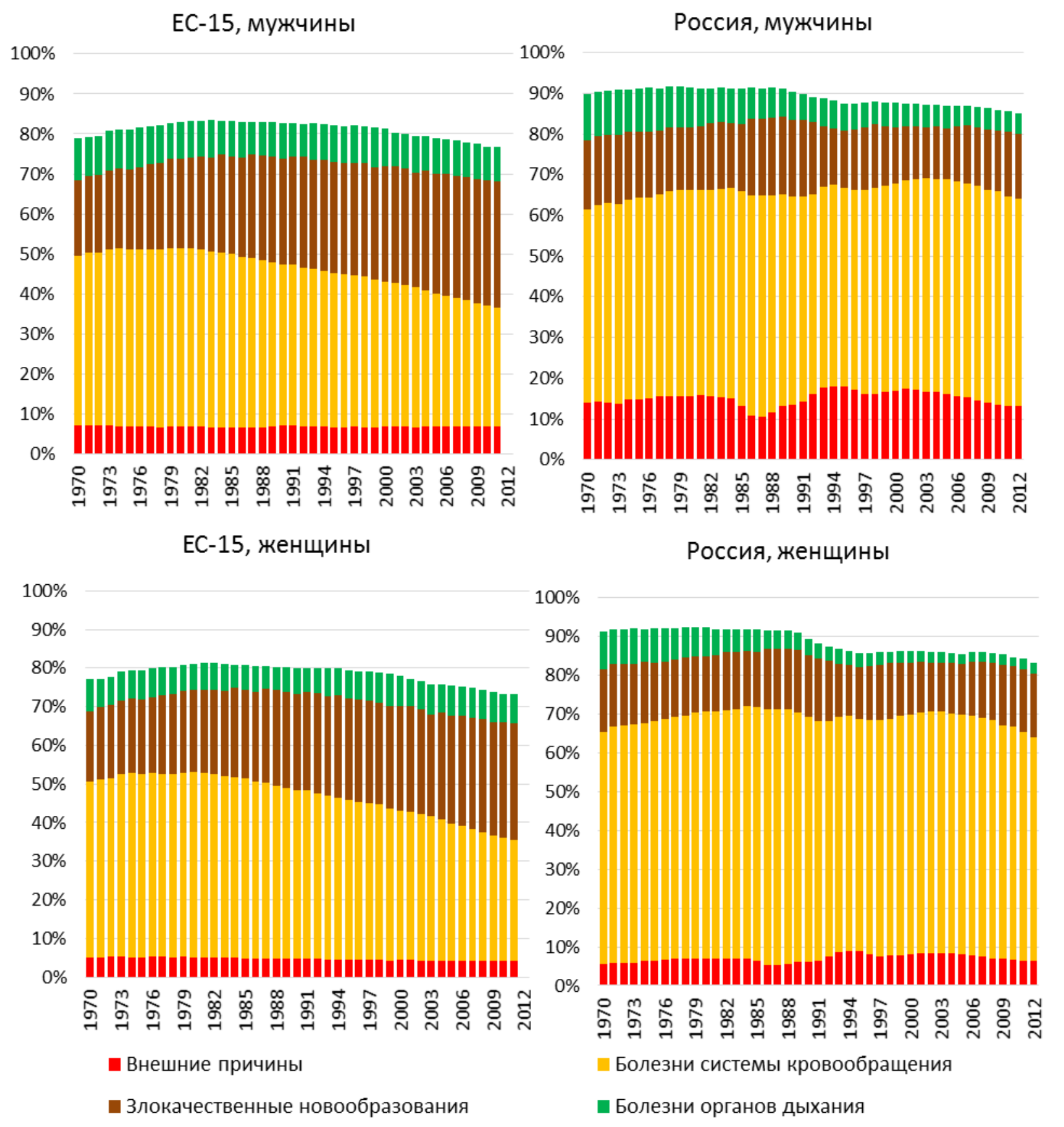

Рисунок 1. Совокупный вклад болезней системы кровообращения, новообразований, болезней органов дыхания и внешних причин в стандартизованный коэффициент смертности от всех причин в России и EC-15

Источники: рассчитано на основе [WНО 2014], данных Росстата.

Соответственно задачи борьбы со смертностью сводились и все еще сводятся прежде всего к снижению смертности от этих четырех классов причин. Если судить по динамике стандартизованного коэффициента смертности, то эти задачи в западноевропейских странах решались весьма успешно, стандартизованный коэффициент смертности от трех из

2 Австрия, Бельгия, Великобритания, Германия, Греция, Дания, Италия, Ирландия, Испания, Люксембург, Нидерланды, Португалия, Финляндия, Франция, Швеция. 
четырех главных классов причин смерти демонстрирует почти синхронное снижение столь быстрое, что и впрямь можно говорить о новой эпидемиологической революции. Только о смертности от рака этого сказать пока нельзя: ее снижение началось позднее, ее уровень до сих пор не слишком сильно оторвался от уровня начала 1970-х годов, хотя в последние два десятилетия заметные позитивные подвижки есть и здесь (рисунок 2).

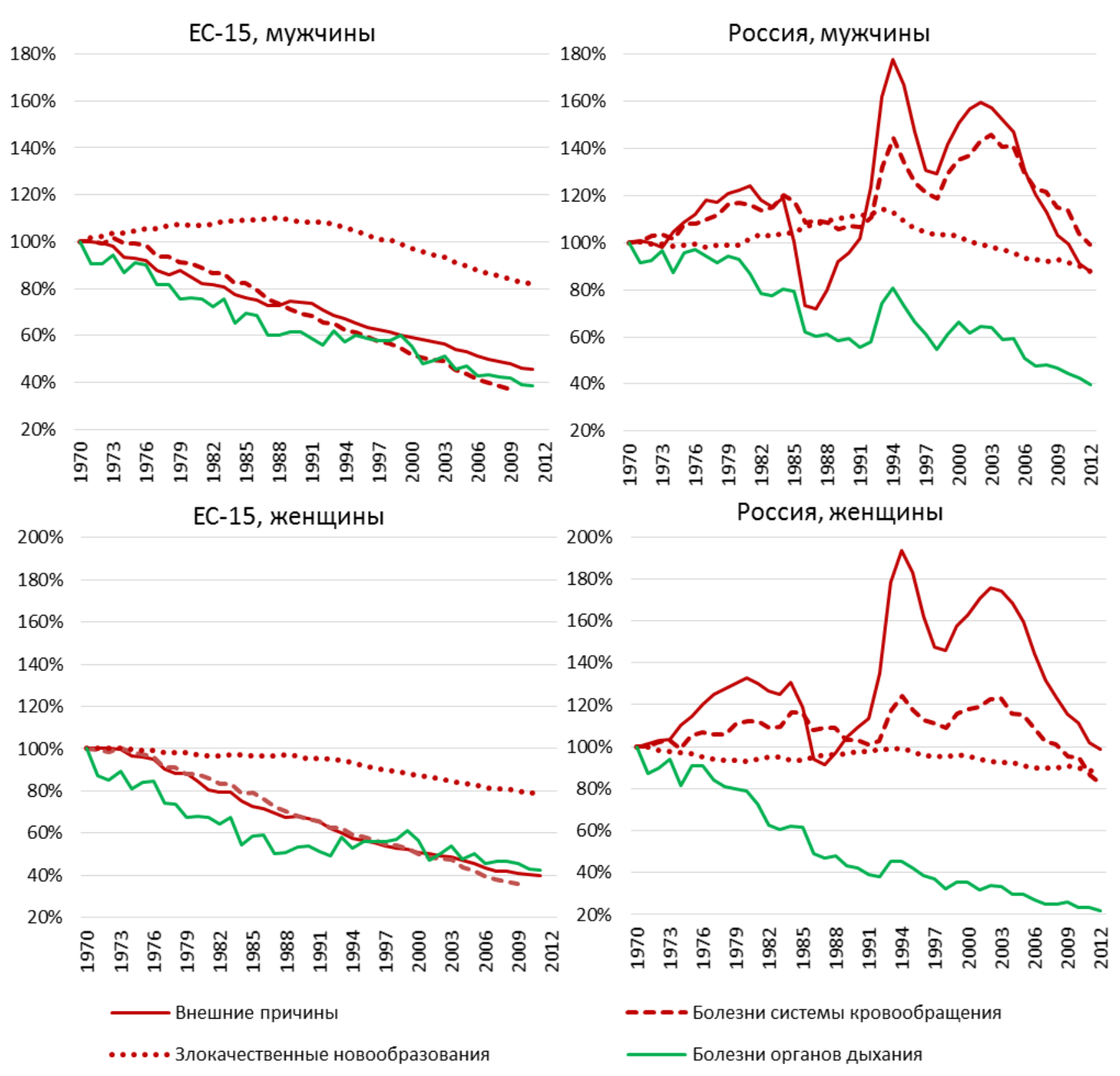

Рисунок 2. Стандартизованный коэффициент смертности от болезней системы кровообращения, новообразований, болезней органов дыхания и внешних причин в России и ЕС-15, 1970 г. $=100 \%$

Источники: рассчитано на основе [WНО 2014], данных Росстата.

В России события развивались по-другому. При значительном структурном сходстве между западноевропейскими странами и Россией уровни смертности от указанных причин в 1970 г., а тем более их последующая динамика очень сильно различались. 
При том, что совокупный вклад в стандартизованный коэффициент смертности причин смерти, входящих в «большую четверку», в странах ЕС-15 изменился не очень сильно (рисунок 1) и эти изменения не носят принципиального характера, его внутренняя структура подверглась очень сильной трансформации. Главное в этой трансформации резкое сокращение вклада болезней системы кровообращения (с 45\% в 1980 г. до 30\% в 2011 г. у мужчин и с 48 до 31\% у женщин) при одновременном росте вклада онкологических заболеваний (с 19\% в 1970 г. до 32\% в 2012 г. у мужчин и с 18 до 30\% у женщин). По сути, вклад этих двух классов причин сравнялся, у мужчин рак даже вышел на первое место. Вклад же двух других классов причин существенно не изменился.

Применительно к России говорить о серьезной трансформации структуры причин смерти не приходится, с 1970 г. она почти не изменилась. Единственное, что можно заметить в российской части графика, это некоторое снижение вклада болезней органов дыхания. Установление контроля над причинами смерти этого класса относилось, скорее, к задачам первой эпидемиологической революции, было ее продолжением и, возможно, поэтому шло в России относительно более успешно.

В то же время обращает на себя внимание чудовищная разница в динамике смертности от внешних причин смерти (рисунок 2). Если в ЕС-15 за четыре десятилетия с 1970 по 2010 г. стандартизованный коэффициент смертности от причин этого класса сократился более чем вдвое (у мужчин на 55\%, у женщин на 60\%), то в России он, пройдя через несколько резких колебаний, по сути вернулся к тому же уровню, на котором находился в 1970 г.

Если в Западной Европе внешние причины смерти устойчиво находятся на четвертом месте, замыкая список «большой четверки» причин, то в России у женщин они еще в 1980-е годы вышли на третье место, а у мужчин они никогда и не опускались ниже третьего места, а нередко поднимались и до второго (рисунок 1). И при этом совокупный стандартизованный коэффициент смертности от «большой четверки» причин смерти как у мужчин, так и у женщин в 1970 г. был намного выше европейского, а в дальнейшем разрыв только увеличивался (рисунок 3 ).

Сказанного достаточно, чтобы утверждать, что, по крайней мере в рассмотренных выше странах Западной Европы, вторая эпидемиологическая революция идет весьма успешно. В России же ее пока приходится считать несостоявшейся.

Однако наш анализ следует продолжить. 
EC-15, мужчины

2500

2000

1500

1000

500

0

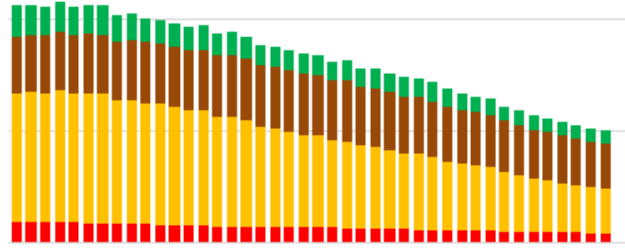

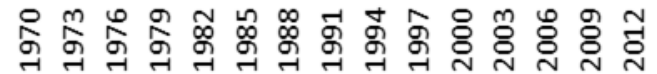

EC-15, женщины

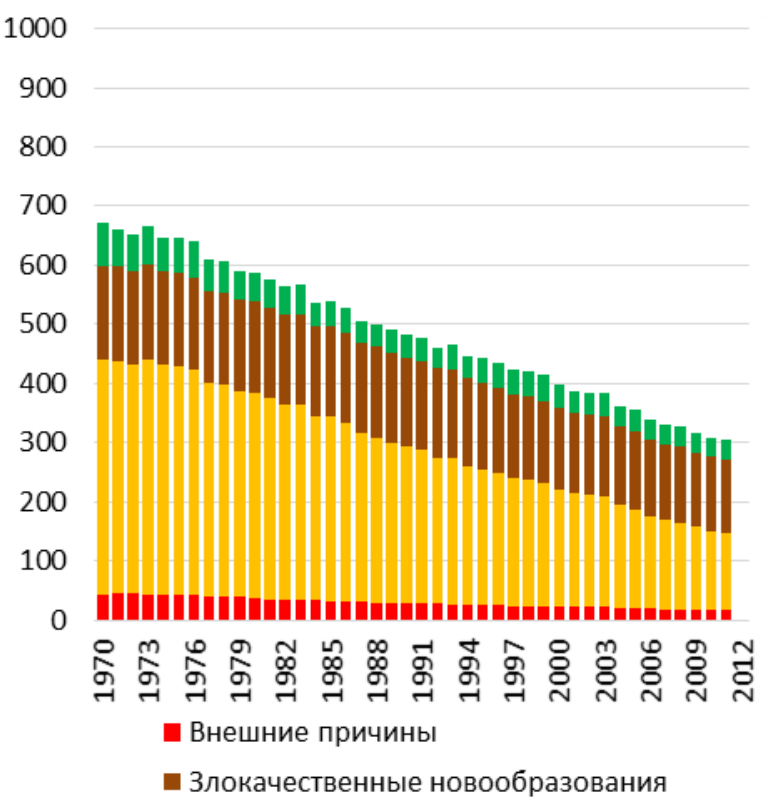

Россия, мужчины

2500

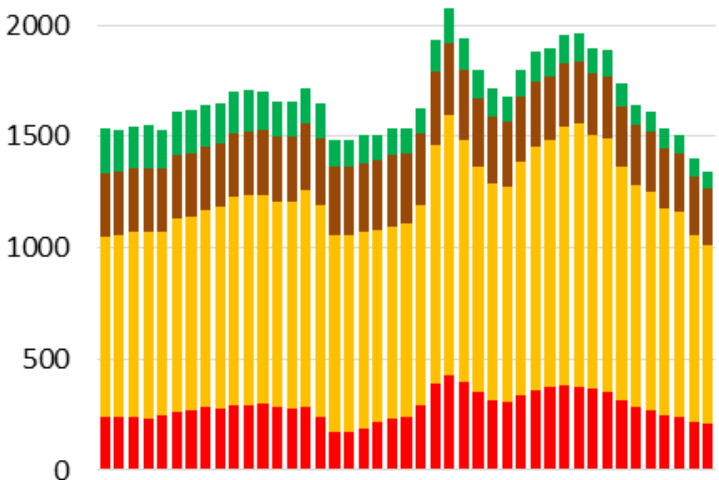

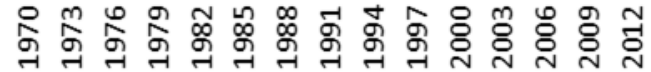

Россия, женщины

1000

900

800

700

600

500

400

300

200

100

0

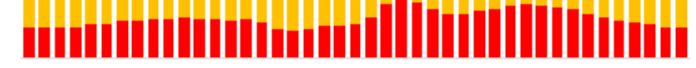

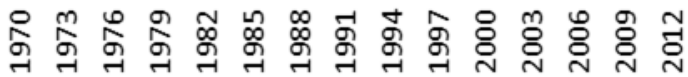

Болезни системы кровообращения

- Болезни органов дыхания

Рисунок 3. Стандартизованный коэффициент смертности от болезней системы кровообращения, злокачественных новообразований, болезней органов дыхания и внешних причин в России и ЕС-15, на 100000

Источники: рассчитано на основе [WНО 2014], данных Росстата.

\section{ТОЛЬКО ЛИ КАРДИОВАСКУЛЯРНАЯ?}

В современной демографической литературе выражение «вторая эпидемиологическая революция», как правило, не используется, но зато широко распространено представление о «кардиоваскулярной революции», которой отводится главное место в происходивших в последние полвека изменениях в смертности. 
Казалось бы, приведенные выше графики не оставляют сомнения в том, что так оно и было, и именно снижение смертности от болезней системы кровообращения определяло всю картину изменений смертности на протяжении последних «революционных» десятилетий. Как можно видеть на примере стран ЕС-15, именно резкое сокращение стандартизованного коэффициента смертности от болезней этого класса и ее доли в смертности «большой четверки» привело к общему снижению коэффициента смертности от четырех причин, взятых вместе. А так как доля большой четверки в общей смертности изменилась незначительно, то снижение смертности от болезней системы кровообращения оказало решающее влияние и на снижение стандартизованного коэффициента смертности от всех причин.

Напомним, однако, об ограничениях аналитических возможностей стандартизованного коэффициента смертности. Этот показатель (удобный инструмент для сравнения между собой разных стран или разных периодов в одной стране) все же не безупречен, в частности, потому, что не позволяет судить о возрастном профиле происходящих изменений, - недостаток, который легко проиллюстрировать на примере смертности от болезней органов дыхания.

Мы видели, что стандартизованный коэффициент смертности от этого класса причин смерти, единственного из «большой четверки», демонстрировал устойчивое снижение в России, даже более быстрое, чем в странах ЕC-15, и, казалось бы, это можно считать российским достижением. В самом деле, в 2011 г. стандартизованный коэффициент смертности российских женщин от болезней органов дыхания был на $33 \%$ ниже, чем жительниц ЕС-15. Однако так ли это хорошо?

Снижение смертности от болезней органов дыхания на протяжении последних 50 лет во всех развитых странах происходило за счет того, что все больше исключались смерти от этого класса причин в младших, особенно детских возрастах. На этом пути были достигнуты необыкновенные успехи, болезни органов дыхания, в основном, сохранили свою роль опасной угрозы только для жизни очень пожилых людей, жизнеспособность которых уже в значительной степени исчерпана. Например, средний возраст смерти от причин этого класса с 1960 по 2010 г. вырос для женщин в США на 10,2 года, во Франции - на 10,3, в Италии - на 17,4, в Японии - на 21,4 года. В России же рост составил всего 5,1 года. В результате женщины в России в 2010 г. умирали от этой причины, в среднем, в 68,6 года, тогда как в США - в 82,2, в Италии - в 87,5, во Франции - в 87,7, в Японии - в 89,8 года. С демографической точки зрения умирать от этой причины в этих странах стало «выгодно», и поэтому надо как-то оценить, насколько позитивным следует считать снижение смертности от этой причины и вообще задуматься над тем, что в данном случае следует понимать под «снижением смертности». А для этого надо уйти от стандартизованного коэффициента смертности и воспользоваться какими-то другими аналитическими инструментами.

По крайней мере, один такой инструмент демографам хорошо известен уже несколько столетий. Речь идет о таблицах смертности по причинам смерти, которые позволяют рассматривать одновременно и изменения возрастного профиля смертности от каждой отдельной причины или группы причин смерти, и вероятности для новорожденного 
из каждой когорты родившихся - условной или реальной (на практике, конечно, чаще приходится иметь дело с условными когортами) - умереть именно от этой причины. Иными словами, показатели таких таблиц позволяют рассматривать изменения смертности по причинам смерти сразу в двух измерениях ${ }^{3}$.

Привычное выражение «снижение смертности» весьма неточно, вероятность смерти для всех людей одинакова и всегда равна 100\%. На самом деле, когда говорят о «снижении смертности», имеется в виду просто оттеснение смертей к старшим возрастам. Но если говорить о снижении смертности от отдельных причин, ход рассуждения должен измениться. Человек может избежать смерти от данной причины, но в этом случае он умрет от какой-либо другой причины, и важно понять, от каких причин умирать предпочтительнее. У разных людей на этот вопрос могут быть разные ответы, но, с точки зрения демографии, исследующей влияние изменений в смертности на рост общей продолжительности жизни, ответ может быть только один: предпочтительнее рост общего числа умерших от тех причин, от которых умирают, в среднем, в более позднем возрасте.

Поскольку причины смерти конкурируют между собой, реальные изменения могут идти в двух направлениях: с одной стороны, может изменяться средний возраст смерти от каждой причины (группы причин) смерти, с другой - вероятность умереть от каждой из них.

В первом случае рост - всегда вклад в «снижение смертности», уменьшение - в ее «повышение». Во втором случае все не так однозначно. Безусловно выгодно только снижение вероятности смерти от причин с более низким средним возрастом смерти. Снижение же вероятности смерти от причин с более высоким средним возрастом смерти выгодно лишь в двух случаях: либо когда такое снижение компенсируется ростом среднего возраста смерти от этой причины, так что совокупное время, прожитое умершими от нее, хотя бы немного увеличивается; либо, если этого нет, то когда эта причина замещается другими с более высоким или растущим средним возрастом смерти. Как правило, происходит и то, и другое, но здесь возникают сложные взаимодействия, оценить результаты которых не всегда просто.

Возьмем для примера изменения смертности мужского населения Франции за 50 лет между 1960 и 2010 гг. и попытаемся понять, в чем заключались эти изменения в терминах причин смерти.

Совокупное время, прожитое поколением, складывается из совокупного времени, прожитого умершими от каждой из причин (или групп причин) смерти. Соответственно произошедшие за 50 лет изменения можно наглядно проиллюстрировать с помощью предложенной в свое время диаграммы [Андреев, Вишневский, Шабуров 1986], представляющей распределение всего прожитого поколением времени по времени, прожитому умирающими от крупных классов причин смерти. По горизонтальной оси на этой диаграмме откладываются вероятности для новорожденного умереть на протяжении жизни от одной из причин $\left(\boldsymbol{P}_{i}\right)$, по вертикальной оси - средний возраст смерти от этой причины или, что то же самое, ожидаемая продолжительность жизни людей, которые от нее

3 В настоящей статье используются таблицы смертности по причинам смерти для России и других стран, построенные и любезно предоставленные автору Е.М. Андреевым. 
умрут $\left(\overline{\boldsymbol{x}}_{\boldsymbol{i}}\right)$. Площадь каждого выделенного цветом прямоугольника - совокупное время, прожитое всеми, умершими от $\boldsymbol{i}$-ой причины, а сумма этих площадей - все совокупное время, прожитое некоторым условным поколением. Понятно, что если $\sum P_{i}=\mathbf{1}$, то

$$
\sum P_{i} \bar{x}_{i}=e_{0} .
$$

На рисунке 4 представлены две такие диаграммы, относящиеся к мужскому населению Франции в начале и конце периода.
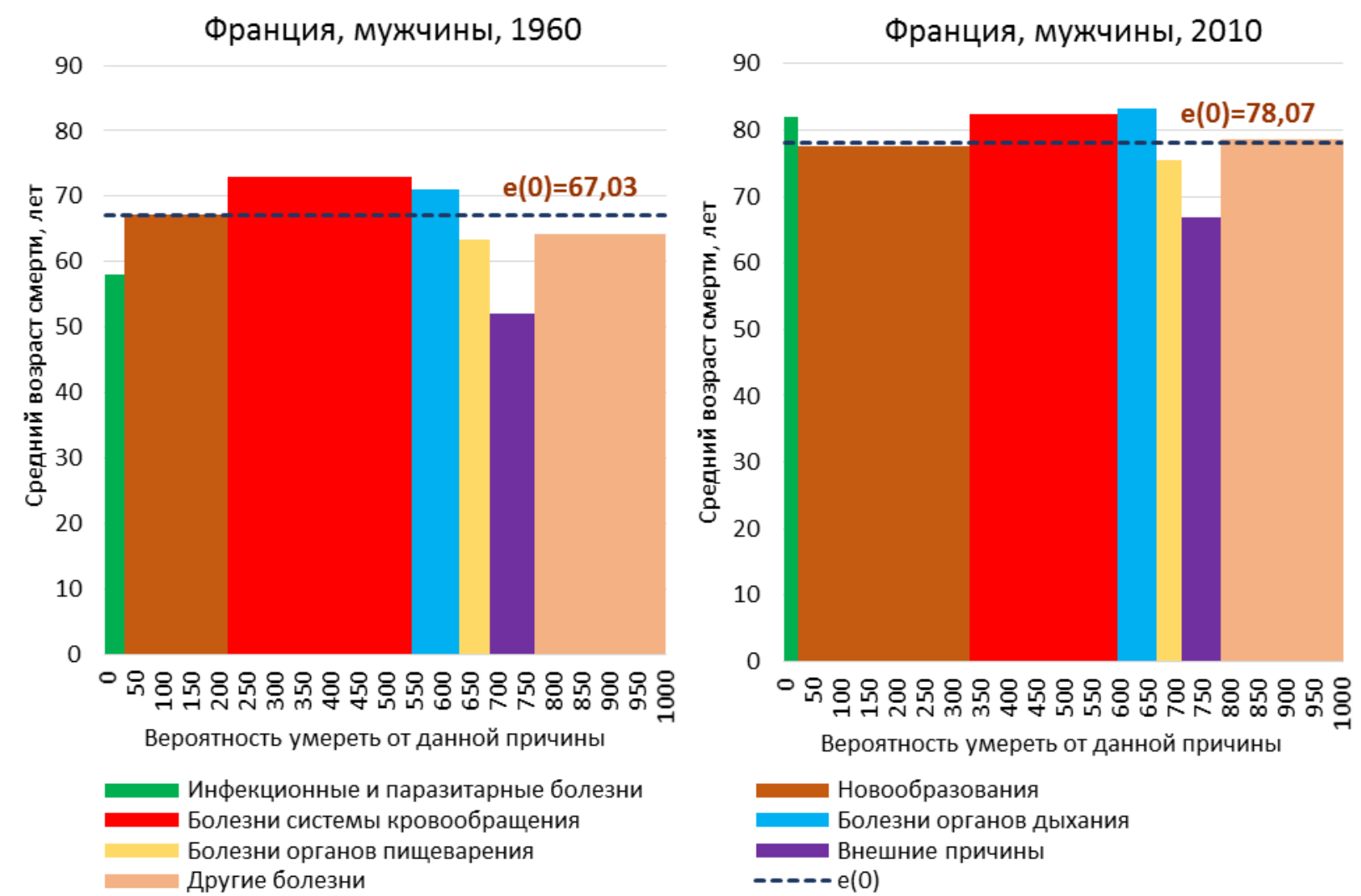

Рисунок 4. Распределение совокупного времени, проживаемого условным поколением, по времени, проживаемому умирающими от крупных классов причин. Франция, мужчины, 1960 и 2010 гг.

Примечание: Пунктирная линия соответствует ожидаемой продолжительности жизни для новорожденного - $е(0)$.

Сопоставление двух графиков на рисунке 4 показывает, что доля умирающих от болезней системы кровообращения в общей численности условной когорты сократилась с 33,1 до 26,4\%, а те, кто все же умирал от БСК, умирали позже, средний возраст смерти от них увеличился на 9,4 года. Прямоугольник, соответствующий этой причине смерти, стал уже и выше, но в целом его площадь даже несколько уменьшилась, а значит, уменьшилась и его доля в общей закрашенной площади, т.к. сама эта площадь выросла. Главное же достижение заключалось в том, что успех в повышении среднего возраста смерти от болезней системы кровообращения был мощно поддержан ростом среднего возраста смерти от тех патологий, которые замещали эти болезни как причину смерти. Если не считать рака, то средний возраст смерти от всех крупных классов причин вырос больше, чем от БСК, в частности, от болезней органов дыхания и пищеварения - более чем на 12 
лет, от внешних причин - почти на 15 лет. Болезни системы кровообращения потеряли свое первенство по среднему возрасту смерти, уступив его болезням органов дыхания. Что же касается рака, риск умереть от которого у мужского населения Франции сейчас выше, чем риск умереть от болезней системы кровообращения, то хотя средний возраст смерти от него увеличился меньше, чем от БСК, рост все же был очень значительным (на 8,4 года), сейчас средний возраст смерти от рака намного выше среднего возраста смерти от любого другого класса причин в 1960 г., включая и БСК, а площадь соответствующего прямоугольника на графике выросла почти вдвое и превзошла площадь прямоугольника БСК. Как это ни парадоксально, но именно рост ожидаемой продолжительности жизни умирающих от рака внес решающий вклад в общее увеличение ожидаемой продолжительности жизни условной когорты: в целом за 50 лет она выросла на 11 лет.

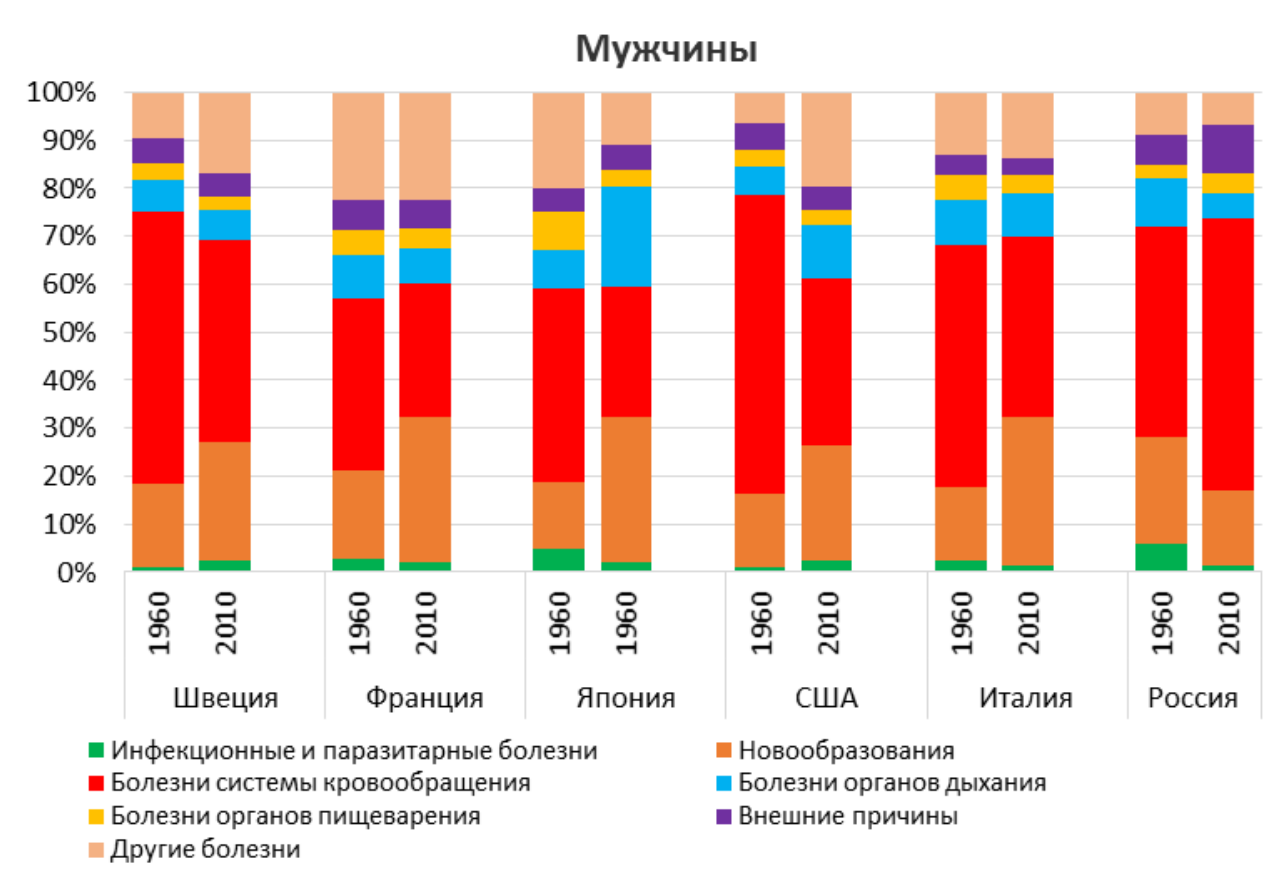

Рисунок 5. Распределение совокупного времени, проживаемого условным поколением, по времени, проживаемому умирающими от крупных классов причин в 1960 и 2010 гг. в некоторых странах, мужчины

Взятое для примера мужское население Франции - не исключение среди развитых стран. Как у мужчин, так и у женщин, изменения в распределении всего совокупного времени, проживаемого условным поколением, по совокупному времени, проживаемому умирающими от крупных классов причин, в большинстве этих стран в главном шли в одном и том же направлении - и не в том, в каком они шли в России (рисунки 5 и 6). При всех различиях между показанными на этих рисунках тремя европейскими странами, США и Японией, в главном прослеживается сходство: сокращается доля совокупного времени, проживаемого умирающими от сердечно-сосудистых заболеваний, но увеличивается доля времени, проживаемого умирающими от рака и от «других болезней» либо, как в случае Японии, от болезней органов дыхания, а в случае США - и от «других болезней», и от болезней органов дыхания. В России же, как видим, изменения противоположные и, кроме того, у мужчин бросается в глаза отсутствующее в других странах заметное увеличение доли совокупного времени, прожитого умирающими от внешних причин. 


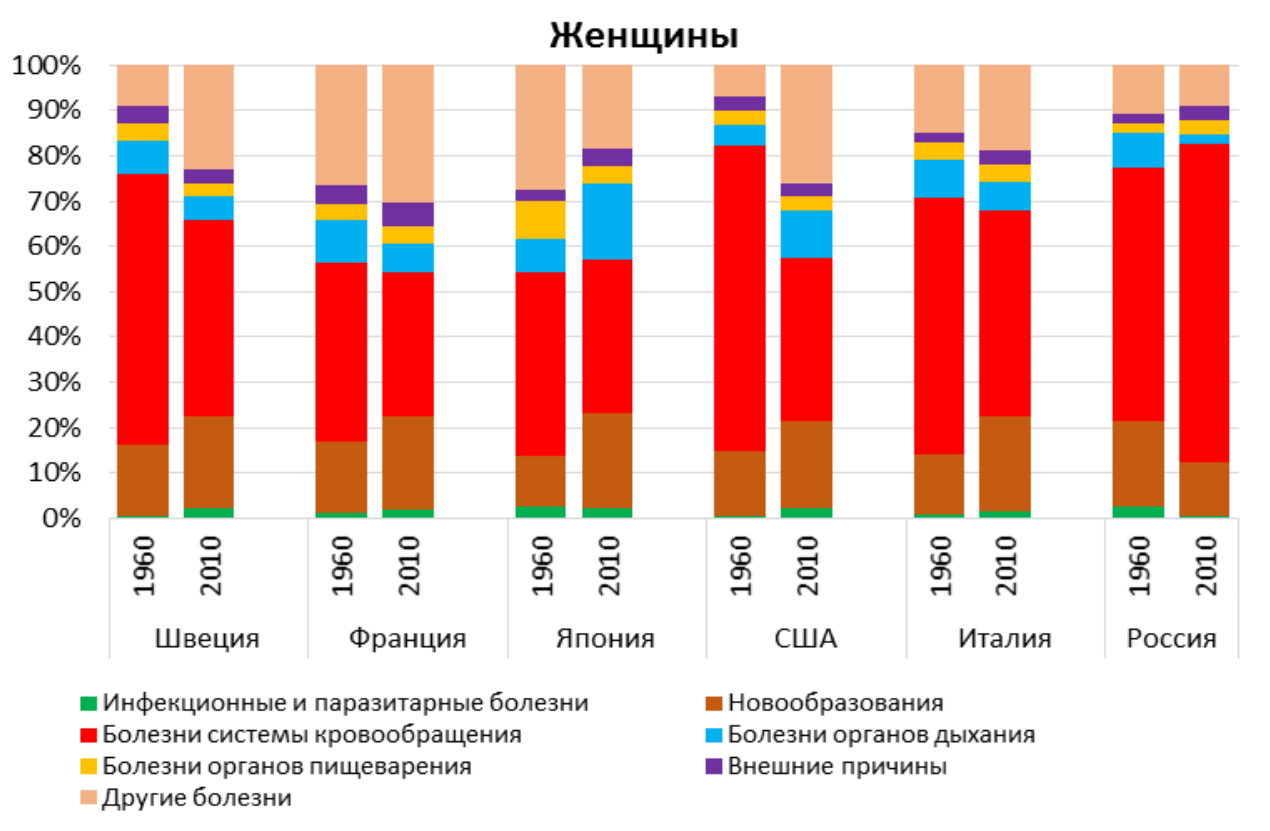

Рисунок 6. Распределение совокупного времени, проживаемого условным поколением, по времени, проживаемому умирающими от крупных классов причин в 1960 и 2010 гг. в некоторых странах, женщины

Характерный для большинства развитых стран (но не для России) тренд, приведший к новой композиции времени жизни людей, умирающих от разных причин смерти, следствие значительного увеличения среднего возраста смерти от всех крупных классов причин (таблица 1). При этом в случае сердечно-сосудистых заболеваний выигрыш в среднем возрасте смерти, как правило, отнюдь не был самым большим.

Таблица 1. Прирост среднего возраста смерти в некоторых странах 3950 лет (1960-2010), лет

\begin{tabular}{l|r|r|r|r|r|r}
\hline Причина смерти & Франция & Италия & Швеция & США & Япония & Россия \\
\hline & Мужчиныь & & & & & \\
Инфекционные и паразитарные болезни & 21,31 & 24,20 & 17,97 & 13,60 & 23,75 & $-8,39$ \\
Новообразования & 8,43 & 10,58 & 7,58 & 8,61 & 12,86 & $-2,47$ \\
Болезни системы кровообращения & 9,39 & 8,82 & 6,78 & 7,38 & 10,46 & $-2,51$ \\
Болезни органов дыхания & 12,15 & 18,70 & 6,14 & 14,53 & 19,89 & 4,66 \\
Болезни органов пищеварения & 12,06 & 18,81 & 7,59 & 8,92 & 11,81 & 3,66 \\
Другие болезни & 14,49 & 21,54 & 17,75 & 29,67 & 14,60 & $-2,10$ \\
Внешние причины & 14,86 & 16,69 & 12,48 & 7,35 & 20,35 & 2,62 \\
Все причины & $\mathbf{1 1 , 0 4}$ & $\mathbf{1 2 , 9 2}$ & $\mathbf{8 , 2 8}$ & $\mathbf{9 , 7 4}$ & $\mathbf{1 4 , 2 4}$ & $\mathbf{- 0 , 5 9}$ \\
& Женщины & & & & & \\
Инфекционные и паразитарные болезни & 26,26 & 35,45 & 22,28 & 20,52 & 33,46 & $-6,33$ \\
Новообразования & 8,95 & 10,59 & 8,17 & 7,84 & 15,87 & $-4,55$ \\
Болезни системы кровообращения & 10,35 & 10,83 & 8,01 & 6,27 & 14,83 & 0,85 \\
Болезни органов дыхания & 10,32 & 17,42 & 5,05 & 10,17 & 21,40 & 5,09 \\
Болезни органов пищеварения & 16,76 & 24,39 & 8,68 & 10,53 & 16,10 & 5,75 \\
Другие болезни & 14,05 & 20,91 & 20,01 & 28,32 & 15,79 & 5,76 \\
Внешние причины & 12,75 & 16,75 & 6,82 & 2,90 & 23,81 & 1,42 \\
Все причины & $\mathbf{1 1 , 1 0}$ & $\mathbf{1 3 , 1 8}$ & $\mathbf{8 , 6 0}$ & $\mathbf{7 , 9 0}$ & $\mathbf{1 6 , 1 5}$ & $\mathbf{2 , 5 6}$ \\
\hline
\end{tabular}

Если не говорить о России, о которой речь пойдет ниже, то столь значительное увеличение среднего возраста смерти от каждой крупной группы причин, а вследствие этого и от всех причин, взятых вместе, собственно, и означает осуществление 
предсказанной М. Террисом «второй эпидемиологической революции», пусть и не столь масштабной, как первая.

Но эта «вторая» революция едва ли сводится к «кардиоваскулярной революции», которая сегодня у всех на слуху. Поистине, революционные изменения затронули всю «большую четверку», да и большинство других причин смерти, сердечно-сосудистые заболевания не демонстрируют каких-то особых, из ряда вон выходящих успехов.

\section{ИЗМЕНЕНИЯ В СМЕРТНОСТИ ЗА ПОЛВЕКА В РОССИИ И ВО ФРАНЦИИ}

Теперь обратимся к России, в которой, как уже отмечалось, вторая эпидемиологическая революция пока не состоялась. В чем конкретно проявляется российская стагнация, и где мы несем наибольшие потери?

Сначала рассмотрим особенности изменений смертности в России за последние полстолетия.

Мы видели, какие огромные изменения в распределении времени жизни мужского поколения по времени, проживаемому умирающими от крупных классов причин смерти, произошли за 50 лет между 1960 и 2010 г. во Франции. Какие-то изменения происходили и в России. Однако если во Франции эти изменения дают все основания говорить о второй эпидемиологической революции, то в России, скорее, напротив, свидетельствуют о ее отсутствии.

Для начала сравним ситуацию в двух странах с помощью графиков на рисунках 4 (Франция) и 7 (Россия).

Различия сразу бросаются в глаза. В России - практически никакого роста высоты основных столбиков при их значительном росте во Франции; расширение основания прямоугольника, соответствующего болезням системы кровообращения при сужении основания прямоугольника новообразований (во Франции - наоборот); значительное расширение низкого столбика внешних причин при том, что во Франции он стал несколько уже, но намного выше; сужение и снижение столбика «других причин» - полная противоположность тому, что наблюдалось во Франции. В итоге сумма закрашенных площадей (т.е. совокупное время, прожитое условным поколением) на российском графике не изменилась, что говорит о полной стагнации, на французском же графике значительно увеличилась, свидетельствуя о приросте средней продолжительности жизни для поколения на 11 лет. 


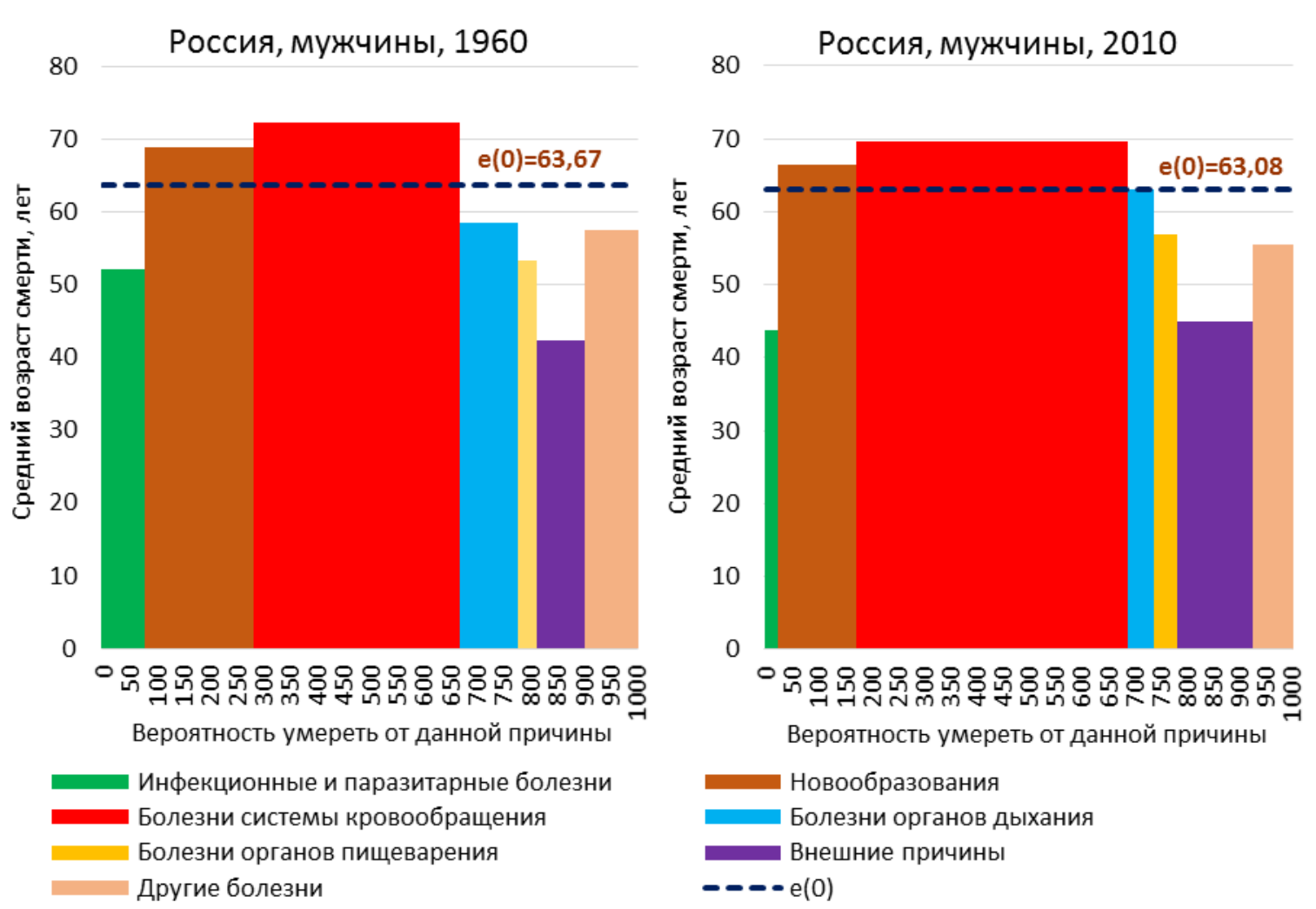

Рисунок 7. Распределение совокупного времени, проживаемого условным поколением, по времени, проживаемому умирающими от крупных классов причин. Россия, мужчины, 1960 и 2010 гг.

Примечание: Пунктирная линия соответствует ожидаемой продолжительности жизни для новорожденного - $е(0)$.

Нынешняя (2010 г.) российская картинка заметно хуже французской картинки пятидесятилетней давности (верхняя часть рисунка 8). А уж ее сравнение с современной французской картинкой (нижняя часть того же рисунка) с очевидностью говорит о потерянных 50 годах: на фоне второй эпидемиологической революции во Франции ни о чем подобном в России говорить не приходится. 

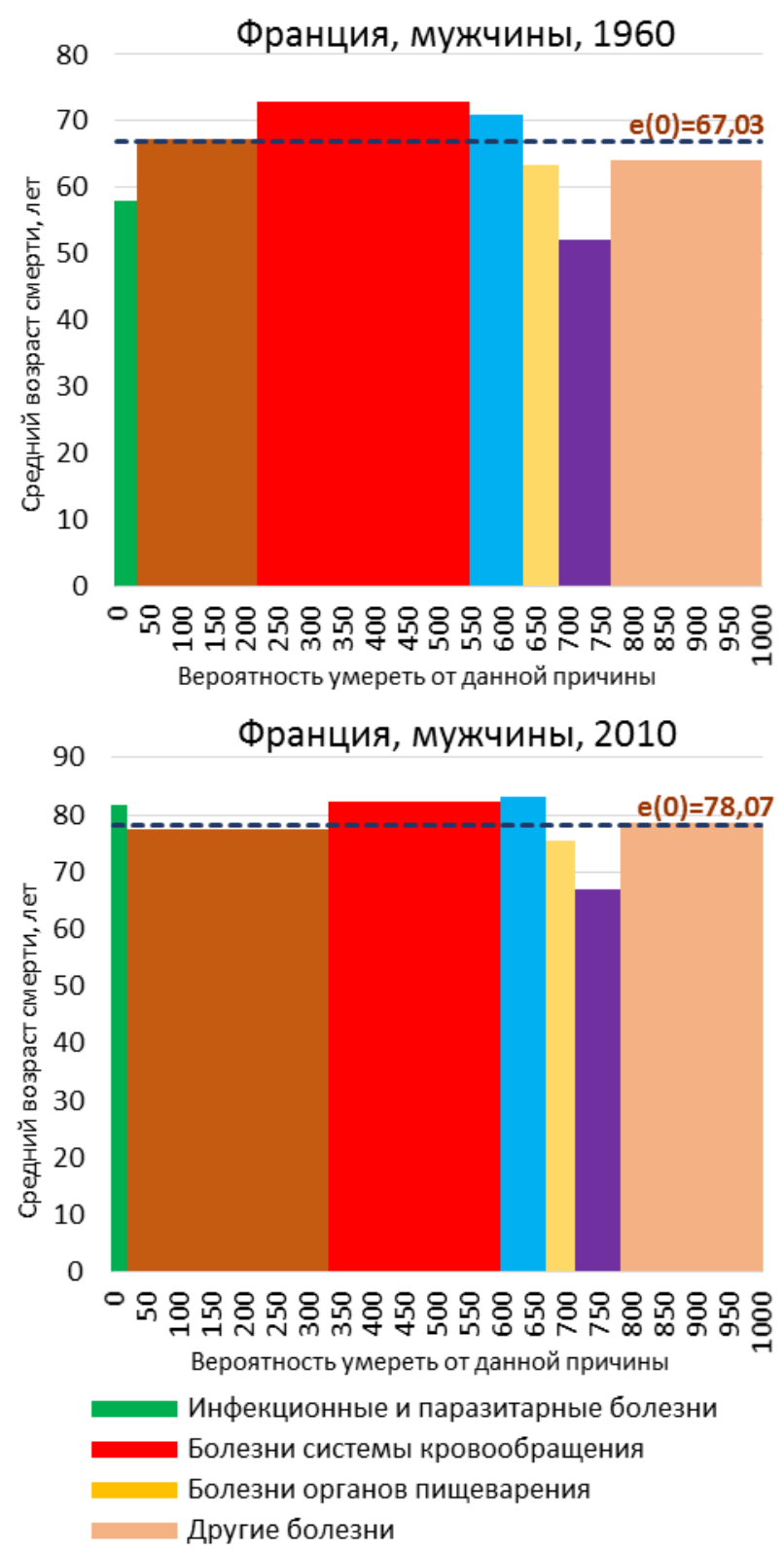

80

Россия, мужчины, 2010

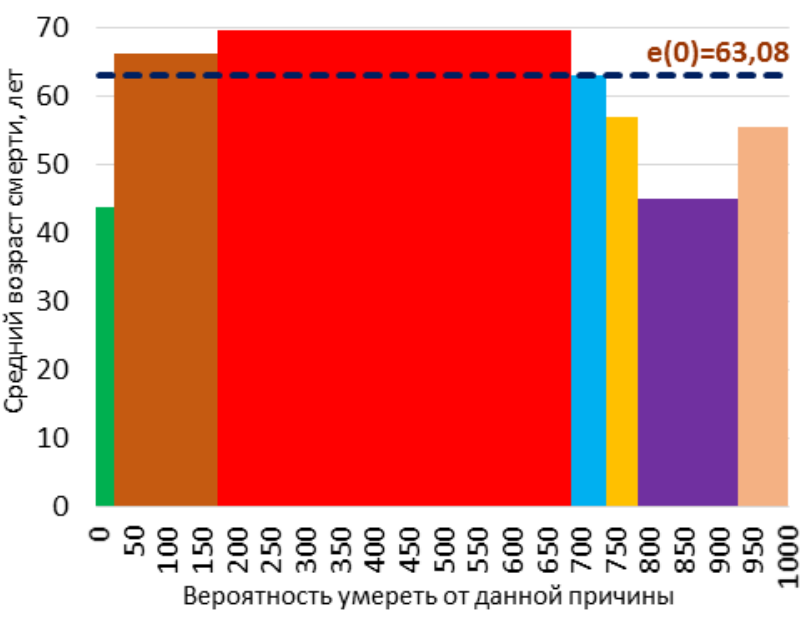

90

Россия, мужчины, 2010

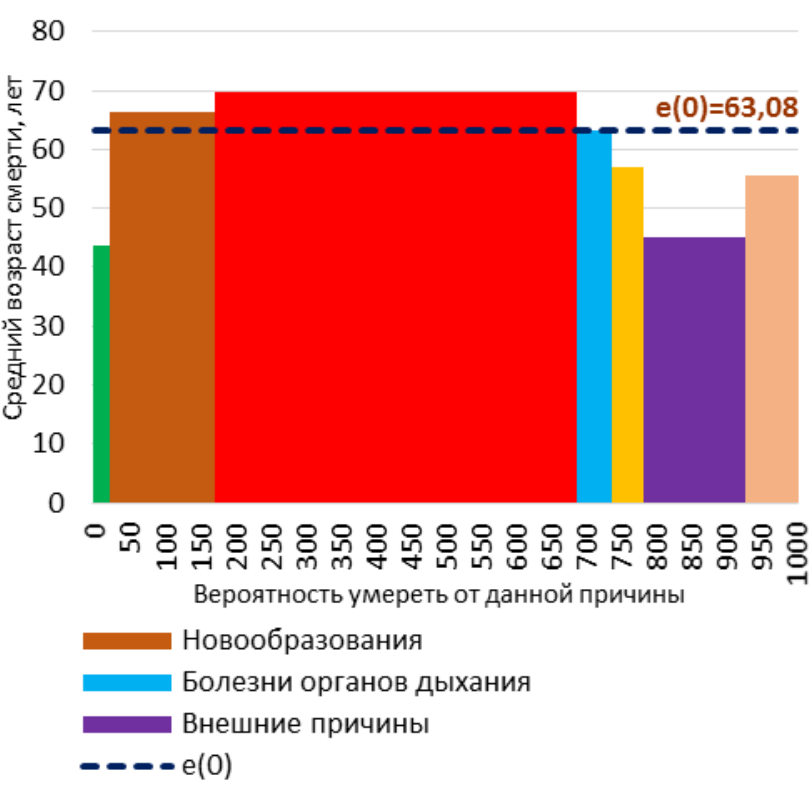

\section{Рисунок 8. Распределение совокупного времени, проживаемого условным} поколением, по времени, проживаемому умирающими от крупных классов причин. Франция, мужчины (1960 и 2010 гг.) и Россия (2010 г.)

Примечание: Пунктирная линия соответствует ожидаемой продолжительности жизни для новорожденного - $е(0)$.

Попытаемся рассмотреть изменения, происходившие в двух странах, более подробно. Для этого также воспользуемся возможностями, предоставляемыми таблицами смертности по причинам смерти, которые содержат, в частности, данные о распределении чисел умирающих по возрасту и причинам смерти - числа $\boldsymbol{d}_{\boldsymbol{x}}(\boldsymbol{x}-$ возраст, $\boldsymbol{i}$ - причина смерти). Это так называемые табличные числа, не зависящие от фактической возрастной структуры.

Сопоставим матрицы изменений чисел $\boldsymbol{d}_{x i}$ в двух странах $\left(2010 d_{x i}-1960 d_{x i}\right)($ таблицы 2$5)$. 
Таблица 2. Изменения чисел умирающих по возрастным группам и причинам смерти между 1960 и 2010 гг. $\left(2010 d_{x i}-1960 d_{x i}\right)$. Мужское население Франции, на 100000 смертей

\begin{tabular}{|c|c|c|c|c|c|c|c|c|}
\hline Возраст & 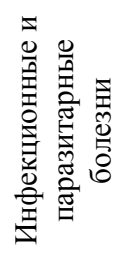 & 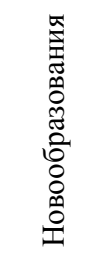 & 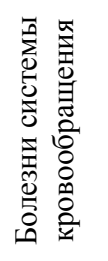 & 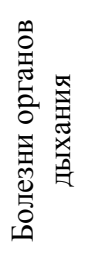 & 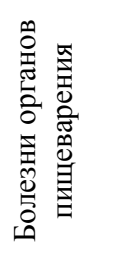 & 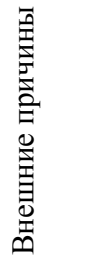 & 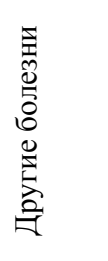 & 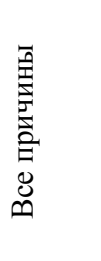 \\
\hline 0 & -73 & -6 & -20 & -291 & -72 & -54 & -2165 & -2681 \\
\hline $1-4$ & -38 & -43 & -13 & -69 & -15 & -96 & -159 & -434 \\
\hline $5-9$ & -11 & -35 & -6 & -9 & -9 & -68 & -31 & -169 \\
\hline $10-14$ & -4 & -25 & -7 & -9 & -8 & -58 & -33 & -144 \\
\hline $15-19$ & -7 & -31 & -17 & -11 & -3 & -149 & -29 & -247 \\
\hline $20-24$ & -16 & -29 & -19 & -10 & -7 & -138 & -33 & -251 \\
\hline $25-29$ & -32 & -37 & -36 & -8 & -23 & -212 & -29 & -377 \\
\hline $30-34$ & -79 & -44 & -61 & -19 & -41 & -197 & -75 & -516 \\
\hline $35-39$ & -107 & -54 & -104 & -40 & -69 & -158 & -68 & -600 \\
\hline $40-44$ & -145 & -60 & -171 & -48 & -106 & -186 & -85 & -802 \\
\hline $45-49$ & -201 & -116 & -380 & -95 & -200 & -220 & -166 & -1378 \\
\hline $50-54$ & -273 & -65 & -689 & -187 & -327 & -283 & -272 & -2096 \\
\hline $55-59$ & -317 & -41 & -1259 & -261 & -439 & -335 & -405 & -3057 \\
\hline $60-64$ & -351 & -99 & -2005 & -408 & -514 & -324 & -696 & -4397 \\
\hline $65-69$ & -296 & 353 & -2956 & -535 & -526 & -217 & -1006 & -5184 \\
\hline $70-74$ & -218 & 852 & -3754 & -692 & -399 & -118 & -1276 & -5605 \\
\hline $75-79$ & -40 & 2034 & -3362 & -671 & -76 & 96 & -1108 & -3127 \\
\hline $80-84$ & 198 & 3278 & -727 & -136 & 248 & 396 & -31 & 3226 \\
\hline $85+$ & 805 & 6929 & 8903 & 2115 & 1100 & 1686 & 6301 & 27839 \\
\hline Всего & -1205 & 12760 & -6683 & -1385 & -1486 & -634 & -1367 & 0 \\
\hline
\end{tabular}

Таблица 3. Изменения чисел умирающих по возрастным группам и причинам смерти между 1960 и 2010 гг. $\left(2010 d_{x i}-1960 d_{x i}\right)$. Мужское население России, на 100000 смертей

\begin{tabular}{|c|c|c|c|c|c|c|c|c|}
\hline Возраст & 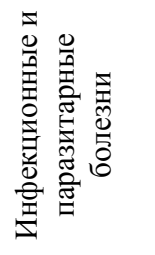 & 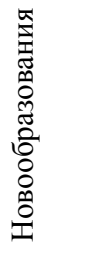 & 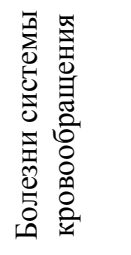 & 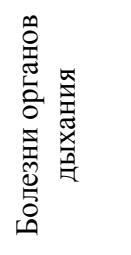 & 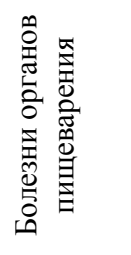 & 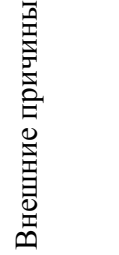 & 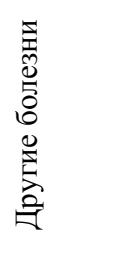 & 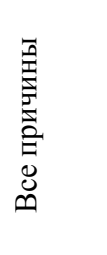 \\
\hline 0 & -416 & -2 & 12 & -1506 & -541 & -17 & -674 & -3144 \\
\hline $1-4$ & -297 & -10 & 0 & -287 & -46 & -92 & -77 & -808 \\
\hline $5-9$ & -83 & -20 & -16 & -35 & -13 & -182 & -35 & -384 \\
\hline $10-14$ & -47 & -11 & -14 & -20 & -10 & -99 & -22 & -223 \\
\hline $15-19$ & -41 & -17 & -35 & -9 & -11 & -52 & -33 & -197 \\
\hline $20-24$ & -74 & -19 & 4 & -5 & 3 & 136 & -6 & 40 \\
\hline $25-29$ & -15 & -23 & 122 & 37 & 75 & 375 & 83 & 653 \\
\hline $30-34$ & 27 & -70 & 290 & 91 & 181 & 662 & 167 & 1349 \\
\hline $35-39$ & -107 & -56 & 520 & 106 & 240 & 439 & 190 & 1331 \\
\hline $40-44$ & -164 & -302 & 651 & 52 & 277 & 811 & 218 & 1541 \\
\hline $45-49$ & -330 & -217 & 1193 & 60 & 301 & 596 & 207 & 1810 \\
\hline $50-54$ & -376 & -452 & 1460 & -105 & 318 & 895 & 234 & 1974 \\
\hline $55-59$ & -685 & -459 & 1935 & -228 & 283 & 498 & 151 & 1495 \\
\hline $60-64$ & -271 & 296 & 1014 & -434 & 354 & 742 & -325 & 1375 \\
\hline $65-69$ & -385 & 139 & 1103 & -562 & 181 & 396 & -569 & 303 \\
\hline $70-74$ & -480 & -297 & 1456 & -668 & 90 & 204 & -788 & -483 \\
\hline $75-79$ & -489 & -846 & 1668 & -654 & -28 & 25 & -721 & -1046 \\
\hline $80-84$ & -452 & -1315 & 872 & -750 & -87 & -93 & -205 & -2030 \\
\hline $85+$ & -511 & -2006 & 498 & -959 & -174 & -186 & -219 & -3557 \\
\hline Всего & -5197 & -5687 & 12734 & -5876 & 1391 & 5058 & -2424 & 0 \\
\hline
\end{tabular}


Таблица 4. Изменения чисел умирающих по возрастным группам и причинам смерти между 1960 и 2010 гг. $\left(2010 d_{x i}-1960 d_{x i}\right)$. Женское население Франции, на 100000 смертей

\begin{tabular}{|c|c|c|c|c|c|c|c|c|}
\hline Возраст & 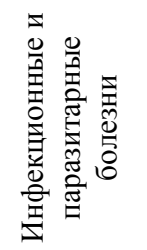 & 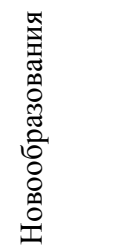 & 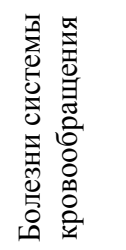 & 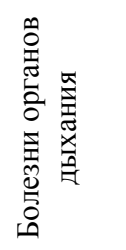 & 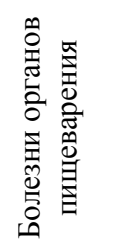 & 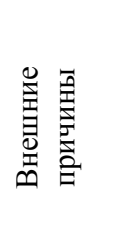 & 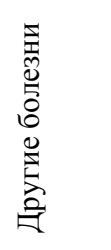 & 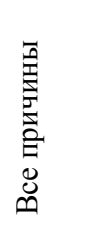 \\
\hline 0 & -62 & -6 & -17 & -212 & -46 & -45 & -1635 & -2024 \\
\hline $1-4$ & -35 & -32 & -6 & -59 & -13 & -64 & -139 & -349 \\
\hline $5-9$ & -11 & -25 & -6 & -9 & -6 & -33 & -36 & -127 \\
\hline $10-14$ & -8 & -20 & -11 & -8 & -5 & -15 & -20 & -87 \\
\hline $15-19$ & -8 & -22 & -12 & -9 & -6 & -50 & -35 & -141 \\
\hline $20-24$ & -22 & -36 & -25 & -10 & -6 & -55 & -62 & -216 \\
\hline $25-29$ & -37 & -25 & -32 & -15 & -20 & -51 & -78 & -259 \\
\hline $30-34$ & -56 & -52 & -45 & -15 & -39 & -44 & -100 & -352 \\
\hline $35-39$ & -65 & -122 & -67 & -21 & -69 & -39 & -113 & -496 \\
\hline $40-44$ & -58 & -148 & -111 & -28 & -108 & -11 & -122 & -586 \\
\hline $45-49$ & -59 & -236 & -230 & -38 & -136 & -26 & -135 & -860 \\
\hline $50-54$ & -64 & -220 & -448 & -51 & -200 & -23 & -181 & -1187 \\
\hline $55-59$ & -69 & -213 & -752 & -76 & -239 & -65 & -306 & -1719 \\
\hline $60-64$ & -78 & -332 & -1378 & -181 & -283 & -88 & -508 & -2848 \\
\hline $65-69$ & -94 & -342 & -2612 & -377 & -319 & -125 & -959 & -4827 \\
\hline $70-74$ & -86 & -296 & -4192 & -689 & -303 & -176 & -1495 & -7237 \\
\hline $75-79$ & -16 & 108 & -5548 & -1085 & -166 & -216 & -1893 & -8818 \\
\hline $80-84$ & 155 & 1199 & -4113 & -1177 & 92 & -102 & -1333 & -5279 \\
\hline $85+$ & 1154 & 6214 & 12978 & 1222 & 1815 & 1905 & 12125 & 37412 \\
\hline Всего & 478 & 5393 & -6626 & -2838 & -59 & 677 & 2975 & 0 \\
\hline
\end{tabular}

Таблица 5. Изменения чисел умирающих по возрастным группам и причинам смерти между 1960 и 2010 гг. $\left(2010 d_{x i}-1960 d_{x i}\right)$. Женское население России, на 100000 смертей

\begin{tabular}{|c|c|c|c|c|c|c|c|c|}
\hline Возраст & 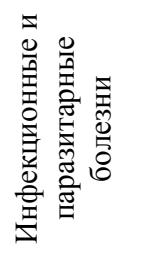 & 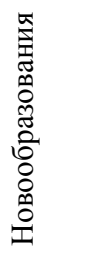 & 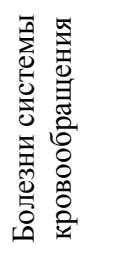 & 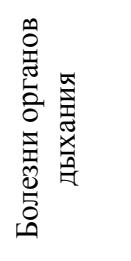 & 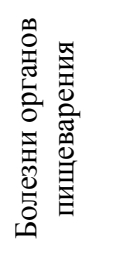 & 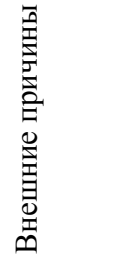 & 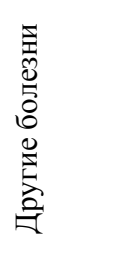 & 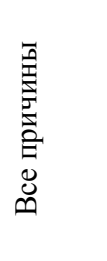 \\
\hline 0 & -379 & -1 & 10 & -1195 & -466 & -14 & -511 & -2557 \\
\hline $1-4$ & -291 & -13 & 0 & -285 & -38 & -63 & -83 & -773 \\
\hline $5-9$ & -77 & -9 & -19 & -33 & -10 & -66 & -33 & -247 \\
\hline $10-14$ & -47 & -9 & -21 & -18 & -7 & -24 & -23 & -149 \\
\hline $15-19$ & -56 & -12 & -35 & -8 & -8 & -6 & -35 & -161 \\
\hline $20-24$ & -78 & -14 & -36 & -4 & 3 & 27 & -70 & -171 \\
\hline $25-29$ & -46 & -11 & -17 & 10 & 38 & 129 & -77 & 26 \\
\hline $30-34$ & -27 & -49 & 14 & 27 & 81 & 182 & -37 & 190 \\
\hline $35-39$ & -97 & -19 & 59 & 20 & 117 & 164 & -67 & 177 \\
\hline $40-44$ & -63 & -191 & 87 & 10 & 141 & 213 & 17 & 215 \\
\hline $45-49$ & -116 & -175 & 196 & 6 & 158 & 177 & 0 & 246 \\
\hline $50-54$ & -106 & -210 & 178 & -40 & 201 & 233 & 50 & 306 \\
\hline $55-59$ & -172 & -301 & 596 & -58 & 304 & 205 & 62 & 636 \\
\hline $60-64$ & -73 & 566 & -451 & -290 & 274 & 249 & -220 & 55 \\
\hline $65-69$ & -124 & 422 & 74 & -414 & 194 & 195 & -441 & -94 \\
\hline $70-74$ & -214 & 1 & 604 & -689 & 132 & 125 & -856 & -897 \\
\hline $75-79$ & -275 & -624 & 3004 & -834 & 111 & 83 & -885 & 580 \\
\hline $80-84$ & -327 & -1457 & 4087 & -1008 & 38 & 11 & -15 & 1328 \\
\hline $85+$ & -521 & -3394 & 6283 & -1652 & -149 & -100 & 821 & 1288 \\
\hline Всего & -3090 & -5501 & 14612 & -6454 & 1115 & 1719 & -2402 & $\mathbf{0}$ \\
\hline
\end{tabular}


Отрицательные значения в таблицах означают уменьшение числа смертей между 1960 и 2010 гг., положительные - увеличение.

Рассмотрим вначале интересующие нас изменения в возрастном разрезе.

В правом, итоговом, столбце французской таблицы для мужчин все числа, за исключением двух последних (в возрасте 80 лет и старше), - отрицательные. Это значит, что во всех возрастах до 80 лет общее число смертей сократилось: из каждых 100000 смертей более 31000 сдвинулись в самые старшие возраста ${ }^{4}$. В российской таблице изменений мало, отрицательные числа, причем часто очень небольшие, относятся к возрастам до 20 и старше 70 лет, здесь число смертей сокращалось. Но зато оно увеличивалось, и довольно заметно, в средних возрастах от 20 до 70 лет именно в эти возрастные группы сдвинулось почти 12000 из каждых 100000 смертей.

Во французской таблице для женщин в правом столбце знаком «минус» отмечены все значения до 85 лет: сдвиг смертей к старшим возрастам заметнее, чем у мужчин, за границу 85 лет сместилось более 37000 из каждых 100000 смертей. Российская таблица для женщин еще больше, чем мужская, характеризует долговременный застой ситуации со смертностью, изменения едва заметны, а там, где они есть, они далеко не всегда благоприятны. Отрицательные значения, говорящие об уменьшении числа смертей, в правом столбце - только в возрастах до 25 лет и 65-74 года. В старшие возраста (75 лет и старше) сдвинулось всего (округленно) 3200 на каждые 100000 смертей, из них на возраста 85 лет и старше - менее 1300 на 100 000. При этом прибавилось 1850 на каждые 100000 смертей в средних возрастах (от 25 до 65 лет). Вся эта картина наглядно отражена на рисунке 9.

Посмотрим теперь, как табличные числа смертей изменялись в разрезе крупных классов причин смерти.

В последней, итоговой, строке французской таблицы для мужчин все числа, за исключением числа смертей от рака, отрицательные, а все приращение числа смертей от рака пришлось на возрасты старше 65, а особенно старше 75 лет. В последней строке российской таблицы число смертей от рака отрицательное, причем, в противоположность Франции, их наибольшее сокращение произошло именно в самых старших возрастах. Но зато примерно на столько, на сколько во Франции увеличилось число смертей от новообразований (12 760 на 100 000), в России выросло число смертей от болезней системы кровообращения (12 734 на 100 000). Разница только в том, что в России почти 90\% этого прироста составили смерти в возрасте до 80 лет, в том числе 62\% - от 35 до 70 лет.

\footnotetext{
4 Заметим, что нынешние оценки чисел $\boldsymbol{d}_{x i}$ для старших возрастов могут оказаться не вполне достоверными из-за традиционного исчисления показателей для «открытого» интервала 85 лет и старше, что было оправдано, когда на этот интервал приходилось относительно небольшое число смертей. Когда же оно стало увеличиваться, потребовалась более детальная разработка данных внутри этого интервала. Сейчас некоторые развитые страны (пока не все) переходят к разработке показателей смертности по причинам смерти с выделением групп 85-89, 90-94, 95+, возможно, в дальнейшем это приведет к уточнению имеющихся сегодня оценок.
} 


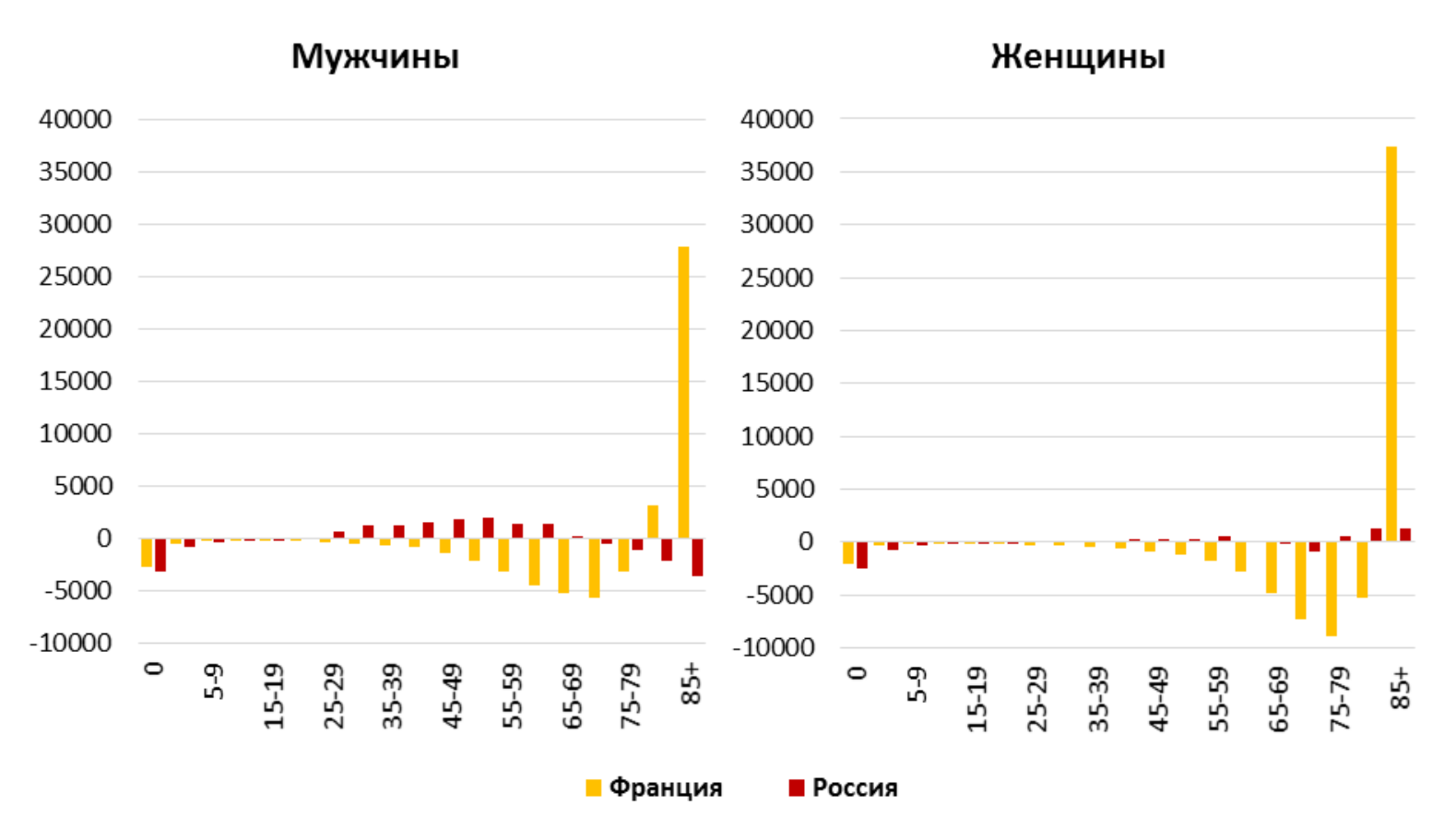

Рисунок 9. Изменения табличных чисел умирающих $\left(d_{x}\right)$ за 1960-2010 гг. по возрастным группам во Франции и в России, на 100000 смертей

Отдельно скажем о внешних причинах смерти. У мужского населения Франции их число увеличилось только в возрастах старше 75, а особенно старше 85 лет, но в целом для всех возрастов оно сократилось. В России это число значительно выросло, причем рост шел во всех возрастных группах от 20 до 80 лет, прирост в возрастах от 20 до 45 лет был большим, чем от болезней системы кровообращения.

Характер различий последних строк французской и российской таблиц для женщин примерно такой же, что и для мужчин. Несколько чаще изменения идут не в противоположном, а в одном и том же направлении, хотя масштаб изменений разный. Например, число смертей от внешних причин у женщин выросло и в России, и во Франции, но во Франции рост был значительно меньшим (см. также рисунок 10).

Если коротко обобщить результаты нашего сравнительного анализа изменений смертности в двух странах, можно сказать, что рядом с безостановочными успехами в оттеснении смерти от всех причин к старшим возрастам во Франции, которая, как мы видели, в этом отношении мало отличается от большинства развитых стран, ситуация в России на протяжении полувека выглядит беспомощным топтанием на месте. 


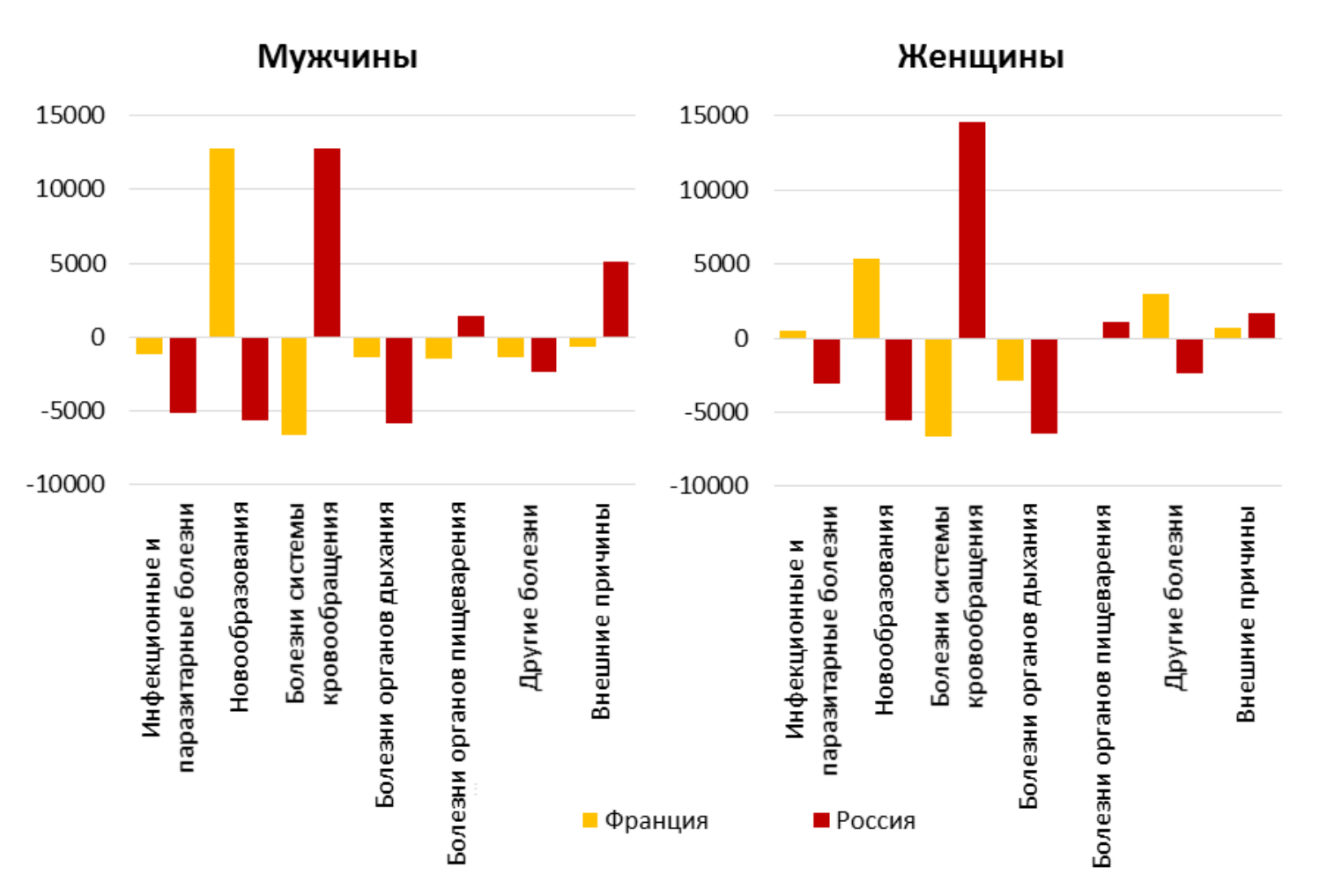

Рисунок 10. Изменения табличных чисел умирающих $\left(d_{x}\right)$ за 1960-2010 гг. по крупным группам причин смерти во Франции и в России, на 100000 смертей

\section{В ЧЕМ ПРОИГРЫВАЕТ РОССИЯ?}

Принес ли какие-нибудь изменения к лучшему последний период российской истории после 1991 г.? Отрицательный ответ на этот вопрос уже отчасти был дан выше при сопоставлении стандартизованных коэффициентов смертности в России и в странах ЕC-15. Но в целях лучшего понимания тенденций последних десятилетий продолжим это сопоставление, обратившись к анализу эволюции возрастных моделей смертности от главных групп неинфекционных причин смерти: сердечно-сосудистых заболеваний, новообразований и внешних причин. Именно в сохраняющихся и даже увеличивающихся различиях этих моделей в странах ЕC-15 и в России - ключ к пониманию нашего отставания.

Начнем с главной причины потерь в России, и (по крайней мере, до недавнего времени) в ЕС-15 - болезней системы кровообращения.

В России у мужчин число смертей от этой причины начинает быстро нарастать уже после достижения 25-летнего возраста, основная масса умирающих от этих причин концентрируется в возрастах до 70-75 лет, после чего их доля даже сокращается (рисунок 11). В странах Западной Европы рост начинается позже (российские показатели, фиксируемые в 25 лет, там не достигаются и к 40 годам), кривые поднимаются гораздо менее круто, но зато этот подъем длится до самых поздних возрастов, так что пик умерших от болезней системы кровообращения приходится не на 70-75 лет, как в России, а ближе к 90 годам. У женщин возрастное распределение смертей от болезней системы 
кровообращения больше похоже на западноевропейское, но все же тоже сильно сдвинуто в сторону более молодых возрастов.

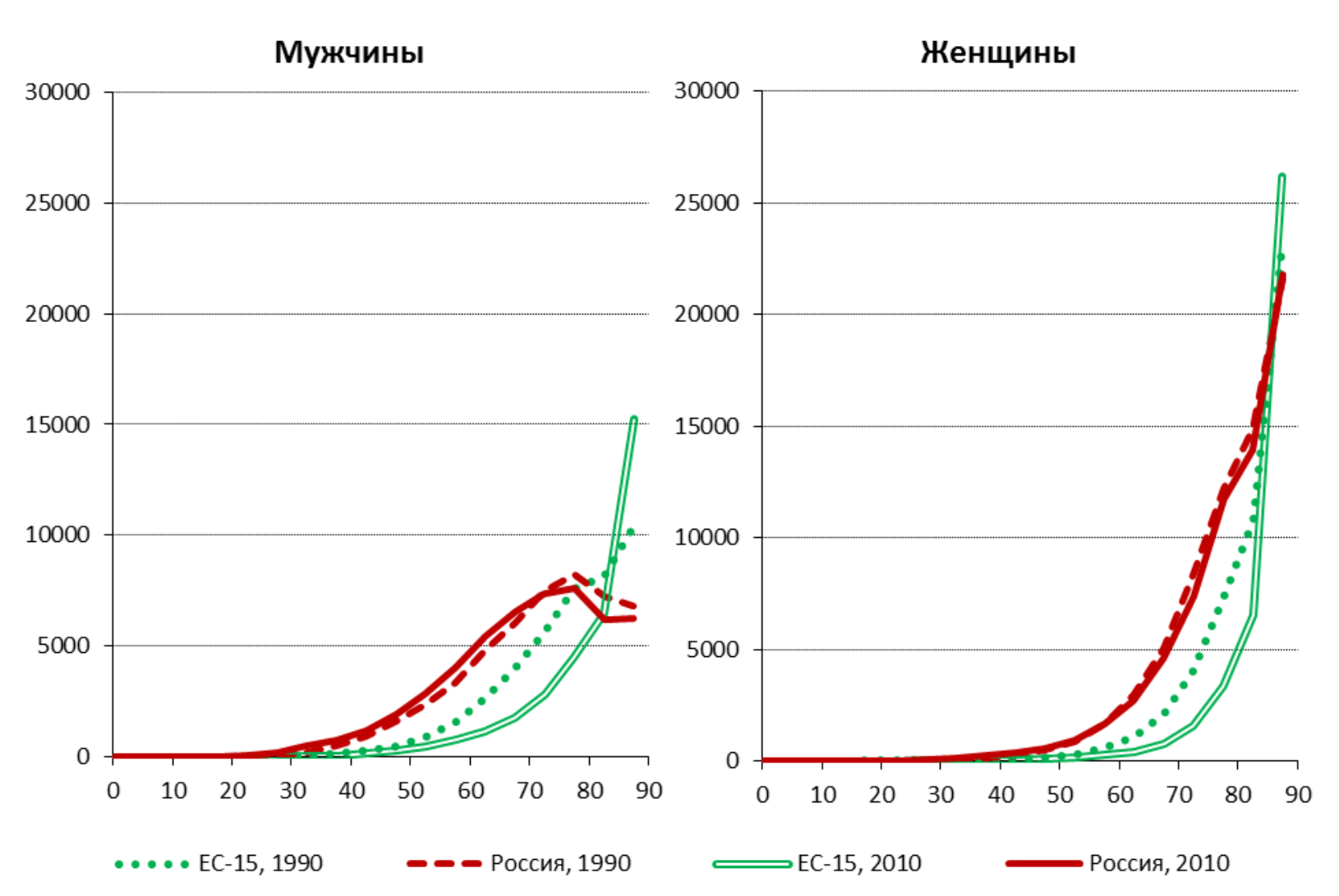

Рисунок 11. Возрастное распределение табличных чисел умирающих $\left(d_{x}\right)$ от болезней системы кровообращения

Несколько иначе выглядит возрастное распределение умирающих от онкологических заболеваний (рисунок 12). Пик числа умерших в России и в этом случае достигается раньше, чем в странах ЕС-15. Но возраст начала роста и крутизна кривых до достижения 60-65 лет в России и в странах ЕС-15 примерно одинаковы. В старших возрастах российские и западноевропейские кривые сильно расходятся, но все же в целом потери от рака разнятся намного меньше, чем от сердечно-сосудистых заболеваний. 


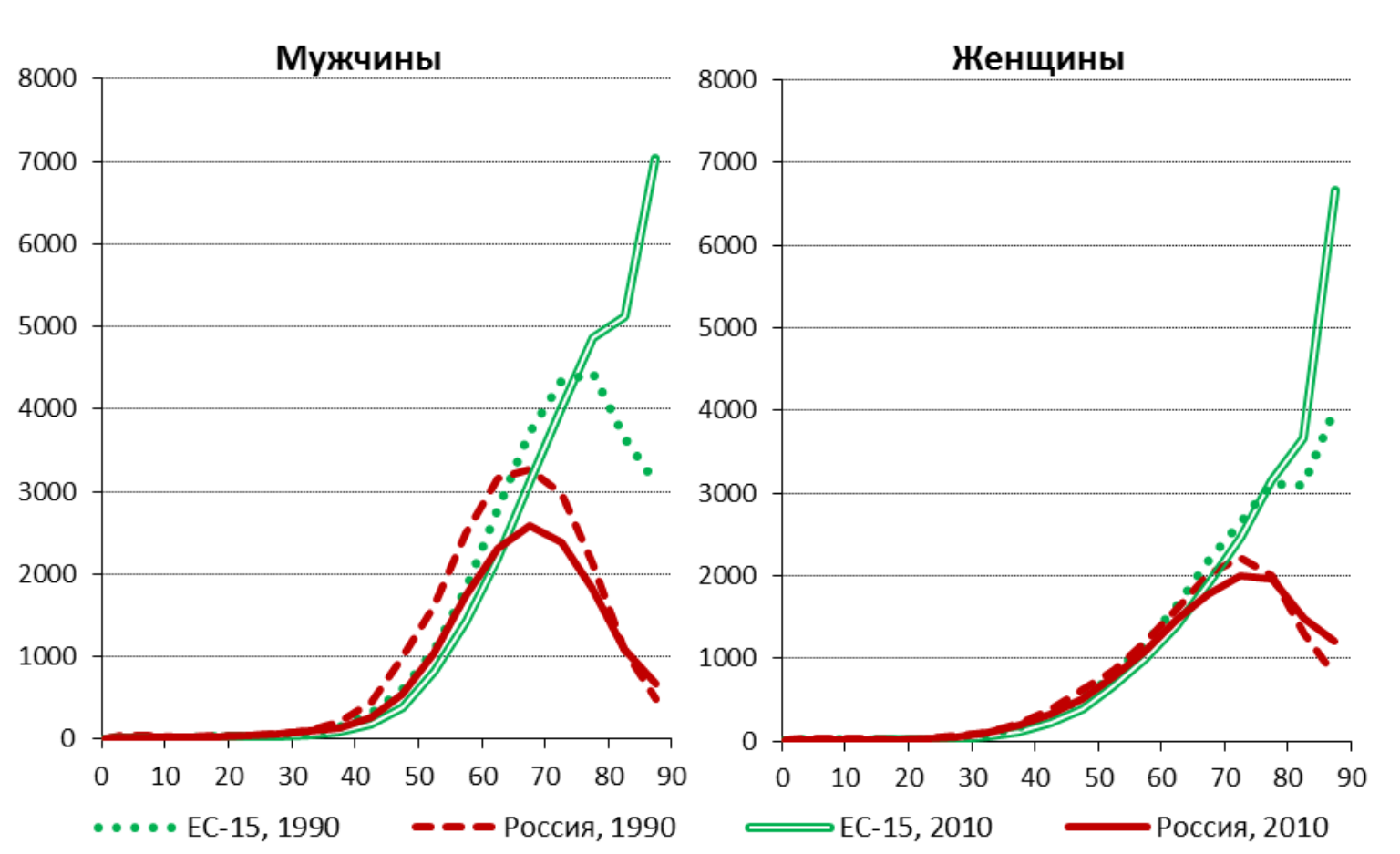

Рисунок 12. Возрастное распределение табличных чисел умирающих $\left(d_{x}\right)$ от новообразований

Но где различия особенно разительны, так это в возрастном распределении смертей от внешних причин (рисунок 13).

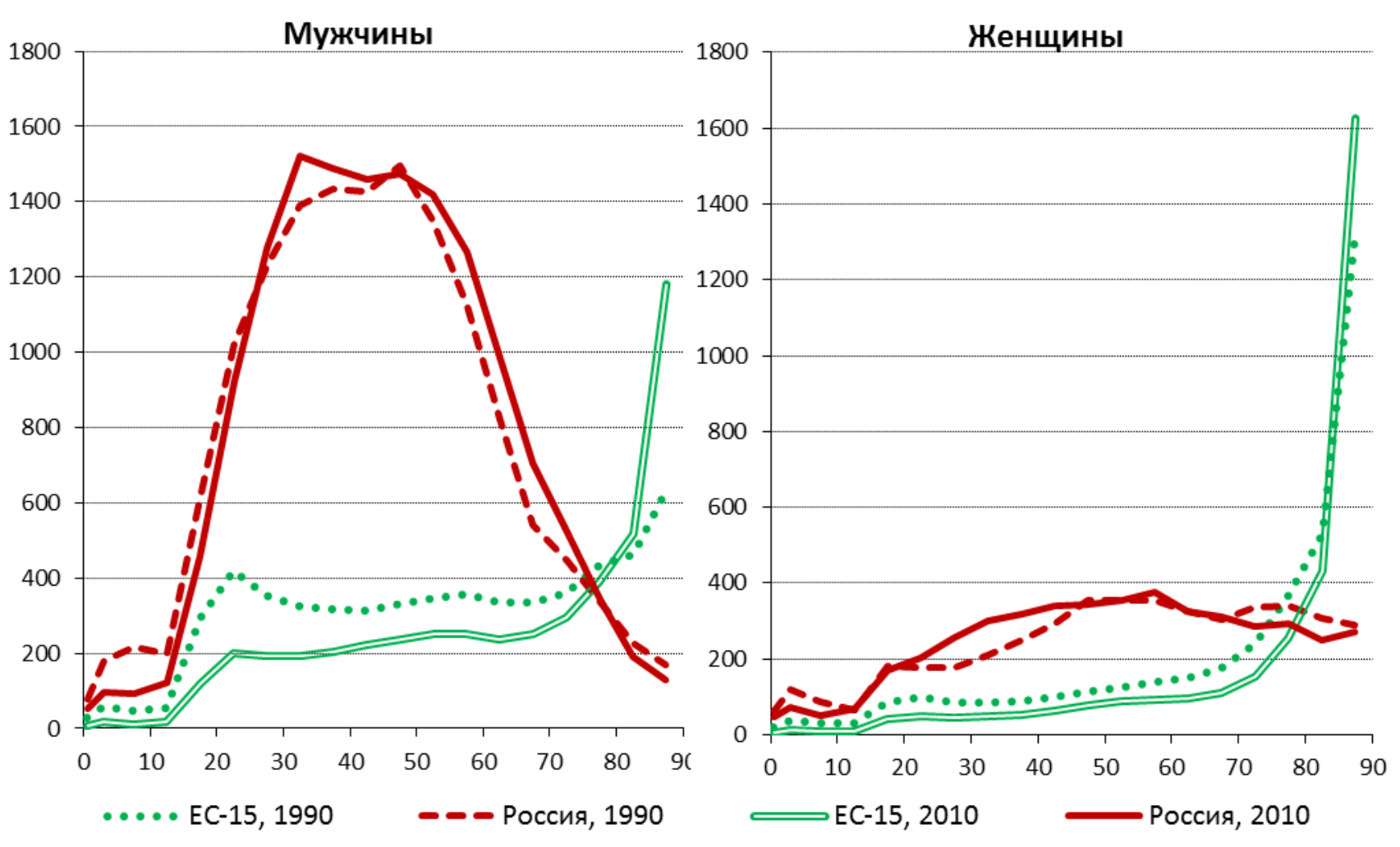

Рисунок 13. Возрастное распределение табличных чисел умирающих $\left(d_{x}\right)$ от внешних причин 
Здесь отличия России от стран ЕС-15 исключительно велики, особенно у мужчин. Создается впечатление, что Россия и западноевропейские страны относятся к разным цивилизациям. Смертность взрослых мужчин от внешних причин смерти в разы выше, чем в сравниваемых странах. Соответственно и потери от этого вида смертности чрезвычайно велики.

Рисунки 11-13 позволяют также судить и об изменениях возрастного распределения чисел умирающих за два десятилетия (между 1990 и 2010 гг.). Кривые для стран ЕС-15 демонстрируют более или менее выраженную тенденцию сдвигаться вниз и вправо, «прогибаясь» в сторону правого нижнего угла графика. При сравнении кривых 1990 и 2010 гг. ясно видно, что правый конец кривых 2010 г. все увереннее устремляется вверх, свидетельствуя о смещении все большего числа смертей от каждого из рассматриваемых классов причин к самым старшим возрастам. Особенно ярко перемены заметны у мужчин, прежде всего в возрастном распределении смертей от рака, где принципиально изменилось направление движения кривой в старших возрастах, хотя достаточно серьезные подвижки произошли и в распределении мужских смертей от болезней системы кровообращения и внешних причин. У женщин тенденция та же, но выражена слабее, возможно потому, что подобные сдвиги произошли у них раньше, еще до 2010 г.

Российские возрастные кривые смертности, особенно для мужчин, как правило, никакого прогиба в сторону правого нижнего угла графика, свидетельствующего об успехах второй эпидемиологической революции, не демонстрируют.

\section{«ИЗБЫТОЧНАЯ СМЕРТНОСТЬ》 И ЕЕ РАСПРЕДЕЛЕНИЕ ПО ВОЗРАСТНО- ПРИЧИННЫМ ГРУППАМ}

Подобно тому, как это уже было сделано выше при сравнении изменений смертности по причинам смерти в России и Франции за 50 лет, можно подробнее рассмотреть и текущие различия в смертности между Россией и странами ЕС-15 с помощью матриц различий или «диагностических таблиц» (впервые такие таблицы были представлены в [Вишневский, Школьников 1997: 78-81]), позволяющих сравнивать распределение всех смертей по возрасту и причинам смерти (чисел $\boldsymbol{d}_{\boldsymbol{x}}$ ) и выделить «возрастно-причинные группы риска» для населения России, указав для каждой из них избыточное по сравнению с ЕС-15 число смертей в возрасте $\boldsymbol{x}$ от причины $\boldsymbol{i}\left(d_{x i}^{R}-d_{x i}^{E U-15}\right)$.

Ограничимся возрастом 70 лет и рассмотрим в качестве преждевременных российских потерь только избыточные по сравнению с западноевропейскими странами (EC-15) смерти до достижения этого возрастного рубежа. Наш анализ будет заключаться в оценке вклада в общую величину таких потерь каждого класса причин по пятилетним возрастным группам и выявлении основных «возрастно-причинных групп», ответственных за эти потери.

В таблицах 6 и 7 приведены избыточные числа смертей для всех выделенных в таблицах возрастно-причинных групп для мужчин и для женщин в условиях смертности 2010 г. 
Таблица 6. Избыточные табличные числа $\left(d_{x i}^{R}-d_{x i}^{E U-15}\right)$ мужских смертей в возрасте до 70 лет в России по сравнению с ЕС-15, на 100000 мужчин, умирающих во всех возрастах и от всех причин, 2010

\begin{tabular}{|c|c|c|c|c|c|c|c|c|}
\hline Возраст & 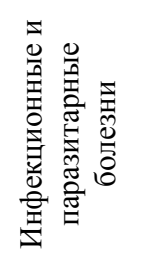 & 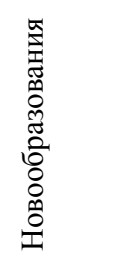 & 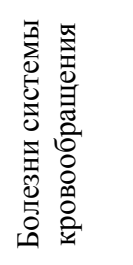 & 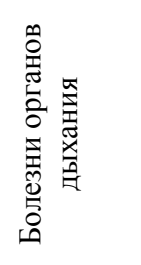 & 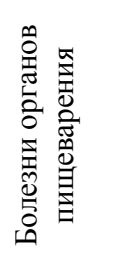 & 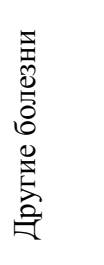 & 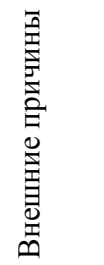 & 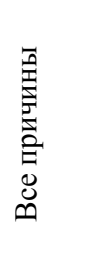 \\
\hline 0 & 99 & 6 & 6 & 176 & 6 & 936 & 97 & 1326 \\
\hline $1-4$ & 28 & 19 & 3 & 58 & 4 & 97 & 154 & 362 \\
\hline $5-9$ & 6 & 13 & 3 & 11 & 2 & 45 & 160 & 240 \\
\hline $10-14$ & 3 & 10 & 5 & 7 & 2 & 26 & 171 & 225 \\
\hline $15-19$ & 16 & 18 & 29 & 18 & 8 & 63 & 685 & 837 \\
\hline $20-24$ & 82 & 22 & 117 & 41 & 29 & 156 & 1603 & 2049 \\
\hline $25-29$ & 147 & 27 & 207 & 63 & 57 & 193 & 1744 & 2437 \\
\hline $30-34$ & 190 & 35 & 375 & 95 & 100 & 197 & 1752 & 2742 \\
\hline $35-39$ & 242 & 78 & 685 & 168 & 145 & 217 & 1845 & 3380 \\
\hline $40-44$ & 289 & 158 & 1225 & 248 & 179 & 258 & 1991 & 4348 \\
\hline $45-49$ & 298 & 317 & 1948 & 360 & 191 & 275 & 2013 & 5402 \\
\hline $50-54$ & 254 & 406 & 2762 & 442 & 176 & 243 & 1806 & 6089 \\
\hline $55-59$ & 196 & 483 & 3570 & 492 & 131 & 115 & 1474 & 6462 \\
\hline $60-64$ & 111 & 47 & 4403 & 507 & 59 & -65 & 994 & 6056 \\
\hline $65-70$ & 2 & -803 & 4649 & 386 & -26 & -353 & 534 & 4390 \\
\hline Всего & 1964 & 836 & 19987 & 3068 & 1063 & 2402 & 17023 & 46344 \\
\hline
\end{tabular}

\begin{tabular}{|l|l|l|l|l|l|}
\hline Число избыточных смертей: & Более 1000 & $500-1000$ & $300-500$ & $100-300$ & $50-100$ \\
\hline
\end{tabular}

Таблица 7. Избыточные табличные числа $\left(d_{x i}^{R}-d_{x i}^{E U-15}\right)$ женских смертей в возрасте до 70 лет в России по сравнению с EC-15, на 100000 женщин, умирающих во всех возрастах и от всех причин, 2010

\begin{tabular}{|c|c|c|c|c|c|c|c|c|}
\hline Возраст & 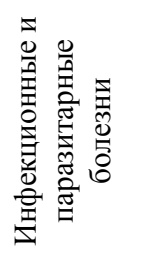 & 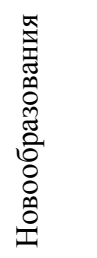 & 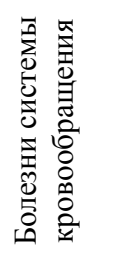 & 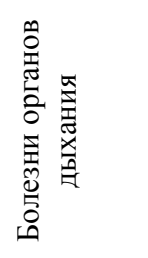 & 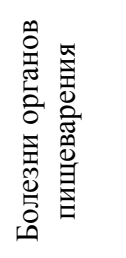 & 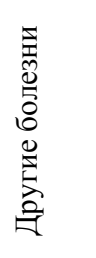 & 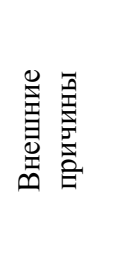 & 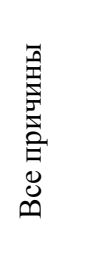 \\
\hline 0 & 71 & 5 & 6 & 139 & 7 & 659 & 83 & 970 \\
\hline $1-4$ & 21 & 17 & 3 & 58 & 2 & 75 & 109 & 284 \\
\hline $5-9$ & 5 & 9 & 4 & 9 & 2 & 31 & 72 & 133 \\
\hline $10-14$ & 3 & 9 & 2 & 4 & 1 & 18 & 70 & 106 \\
\hline $15-19$ & 10 & 14 & 12 & 8 & 4 & 38 & 216 & 302 \\
\hline $20-24$ & 23 & 21 & 26 & 15 & 9 & 60 & 285 & 440 \\
\hline $25-29$ & 31 & 31 & 51 & 19 & 22 & 65 & 300 & 518 \\
\hline 30-34 & 36 & 60 & 100 & 29 & 31 & 77 & 320 & 653 \\
\hline $35-39$ & 36 & 89 & 171 & 39 & 46 & 81 & 362 & 825 \\
\hline $40-44$ & 41 & 133 & 327 & 51 & 68 & 84 & 408 & 1112 \\
\hline $45-49$ & 35 & 191 & 613 & 73 & 83 & 107 & 466 & 1568 \\
\hline $50-54$ & 30 & 200 & 1117 & 73 & 109 & 119 & 504 & 2152 \\
\hline $55-59$ & 20 & 188 & 1981 & 71 & 162 & 124 & 506 & 3051 \\
\hline $60-64$ & 0 & 41 & 3065 & 43 & 122 & 44 & 380 & 3696 \\
\hline $65-70$ & -28 & -171 & 5182 & 30 & 102 & -72 & 312 & $\mathbf{5 3 5 5}$ \\
\hline Всего & 333 & 837 & 12659 & 662 & 772 & 1510 & 4393 & 21165 \\
\hline
\end{tabular}


Цифра в правом нижнем углу таблиц показывает, что в 2010 г. в России, по сравнению со странами ЕС-15, из каждых 100000 мужских смертей во всех возрастах более 46 000, а из каждых 100000 женских смертей более 21000 можно было считать избыточными, в ЕС-15 они наступили бы уже после достижения 70 лет. Итоговые строки таблиц показывают, что порядка 80\% всех избыточных смертей (79,9\% у мужчин и 80,6\% у женщин), обусловлены двумя классами причин смерти: болезнями системы кровообращения и внешними причинами. В целом, конечно, первенствуют болезни системы кровообращения, но до достижения возраста 50 лет у мужчин и 45 лет у женщин это не так. До указанных возрастов главный источник нашей избыточной смертности внешние причины смерти. Вклад всех остальных причин смерти значительно меньше.

Подобные «диагностические таблицы» были составлены и для 1990 и 2000 г. (см. Приложение). Обобщенная картина отставания России от стран ЕС-15 вследствие различий в смертности от разных причин смерти на три даты (1990, 2000, 2010 г.) представлена на рисунке 14. На графике ясно виден как общий рост этого отставания, так и непозволительно высокий вклад в это отставание внешних причин смерти, у мужчин они все время почти конкурируют с болезнями системы кровообращения.

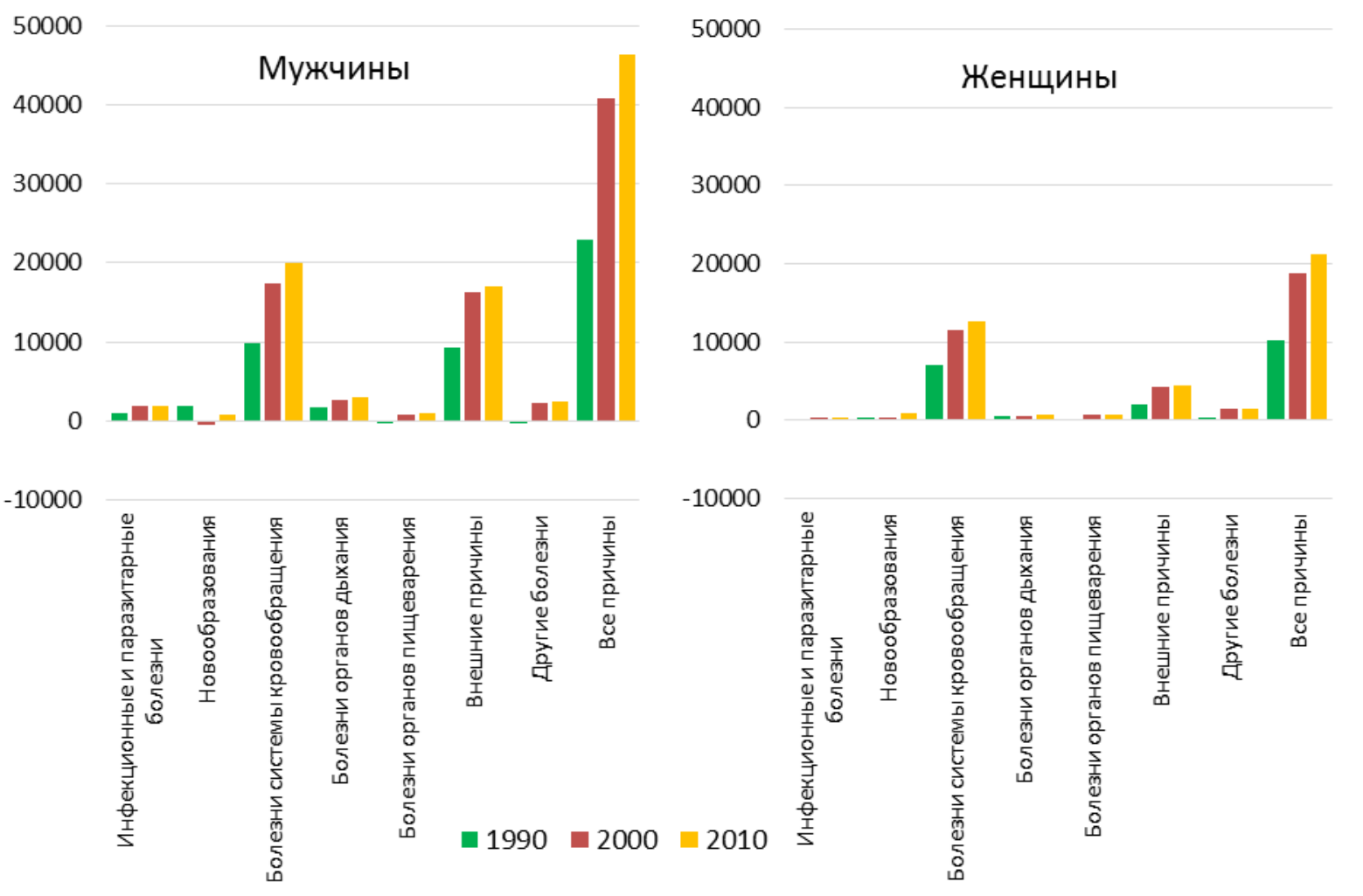

Рисунок 14. Избыточные табличные числа умерших от различных причин $\left(d_{i}\right)$ в возрасте до 70 лет на 100 умерших во всех возрастах в России по сравнению со средними значениями для стран ЕС-15, 1990, 2000 и 2010 г. 


\section{ПРИЧИНЫ СМЕРТИ И ОЖИДАЕМАЯ ПРОДОЛЖИТЕЛЬНОСТЬ ЖИЗНИ}

Избыточная по сравнению со странами ЕС-15 смертность от некоторых важнейших причин смерти в относительно молодых возрастах предопределяет значительное отставание России от этих стран по ожидаемой продолжительности жизни. В 2010 г. разница составляла для мужчин 15,4 года, для женщин 8,9 года, ее декомпозиция по методу Андреева [Андреев 1982] позволяет судить о вкладе в наше отставание крупных классов причин смерти (рисунки 15 и 16).

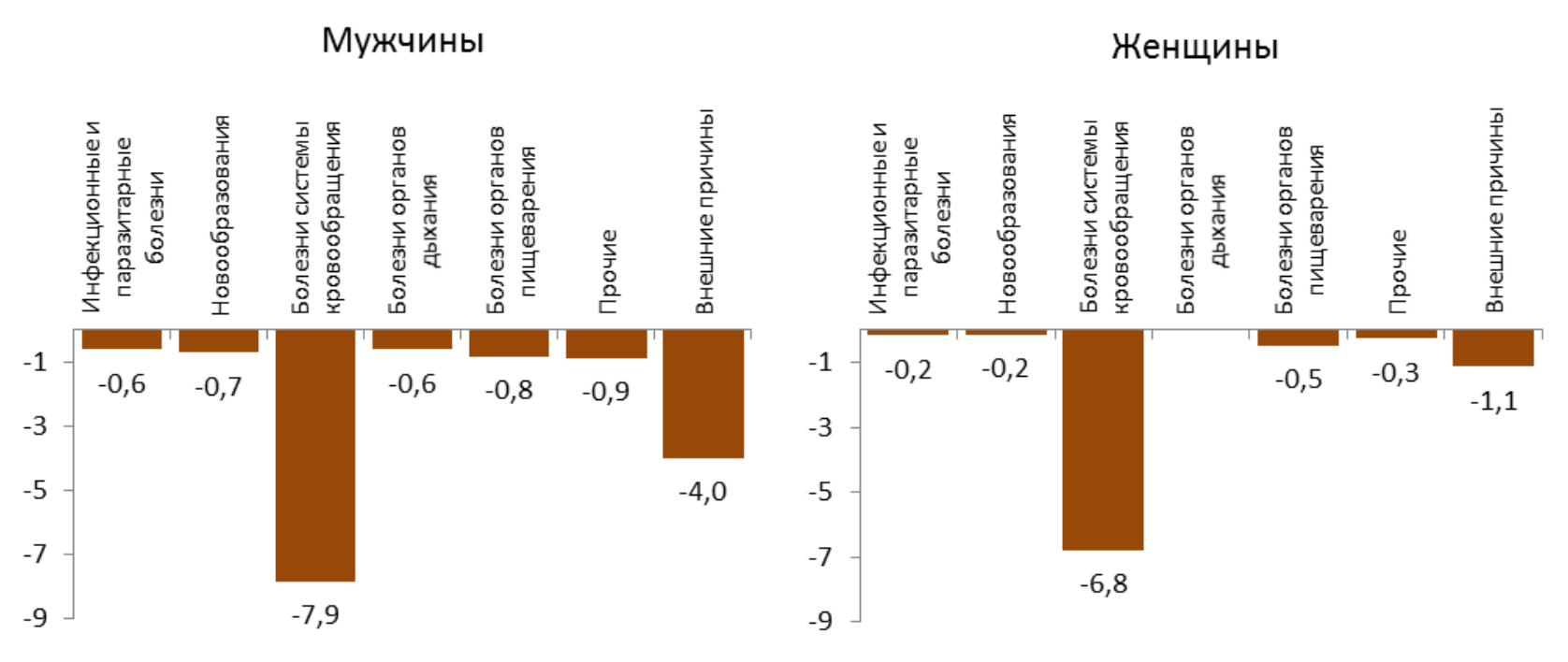

Рисунок 15. Общие потери в ожидаемой продолжительности жизни в России по сравнению со странами ЕC-15 в результате различий в смертности от крупных классов причин смерти, 2010, лет

Таблица 8. Вклад более высокой смертности от болезней системы кровообращения и внешних причин смерти в общее отставание России от ЕС-15 по ожидаемой продолжительности жизни, 2010, \%

\begin{tabular}{lcc|c|c}
\hline \multirow{2}{*}{ Причина смерти } & \multicolumn{2}{|c|}{ Во всех возрастах } & \multicolumn{2}{c}{ В возрастах до 70 лет } \\
\cline { 2 - 5 } & мужчины & женщины & мужчины & женщины \\
\hline Болезни системы кровообращения & 50,9 & 76,2 & 38,6 & 45,2 \\
Внешние причины смерти & 25,9 & 12,7 & 31,2 & 21,6 \\
Итого & 76,8 & 88,9 & 69,8 & 66,8 \\
\hline
\end{tabular}

Как и следовало ожидать, главный вклад в российское отставание от ЕС-15 и у мужчин, и у женщин вносят все те же два класса причин: болезни системы кровообращения и внешние причины смерти. Более высокая смертность от этих двух классов причин на 77\% обусловливает российское отставание по продолжительности жизни мужчин и еще больше (на 89\%) для женщин. При этом, если рассматривать различия в смертности на всей возрастной шкале, то вклад болезней системы кровообращения существенно выше, чем внешних причин. Но если ограничиться только возрастами до 70 лет (рисунок 16 и таблица 8), то преобладание болезней системы кровообращения становится гораздо менее выраженным. Это особенно заметно у мужчин: вклад смертности от внешних причин в 
общее отставание от ЕС-15 приближается к вкладу болезней системы кровообращения (25,9 и 50,9\% для всех возрастов, но 31,2 и 38,6\% в возрасте до 70 лет).

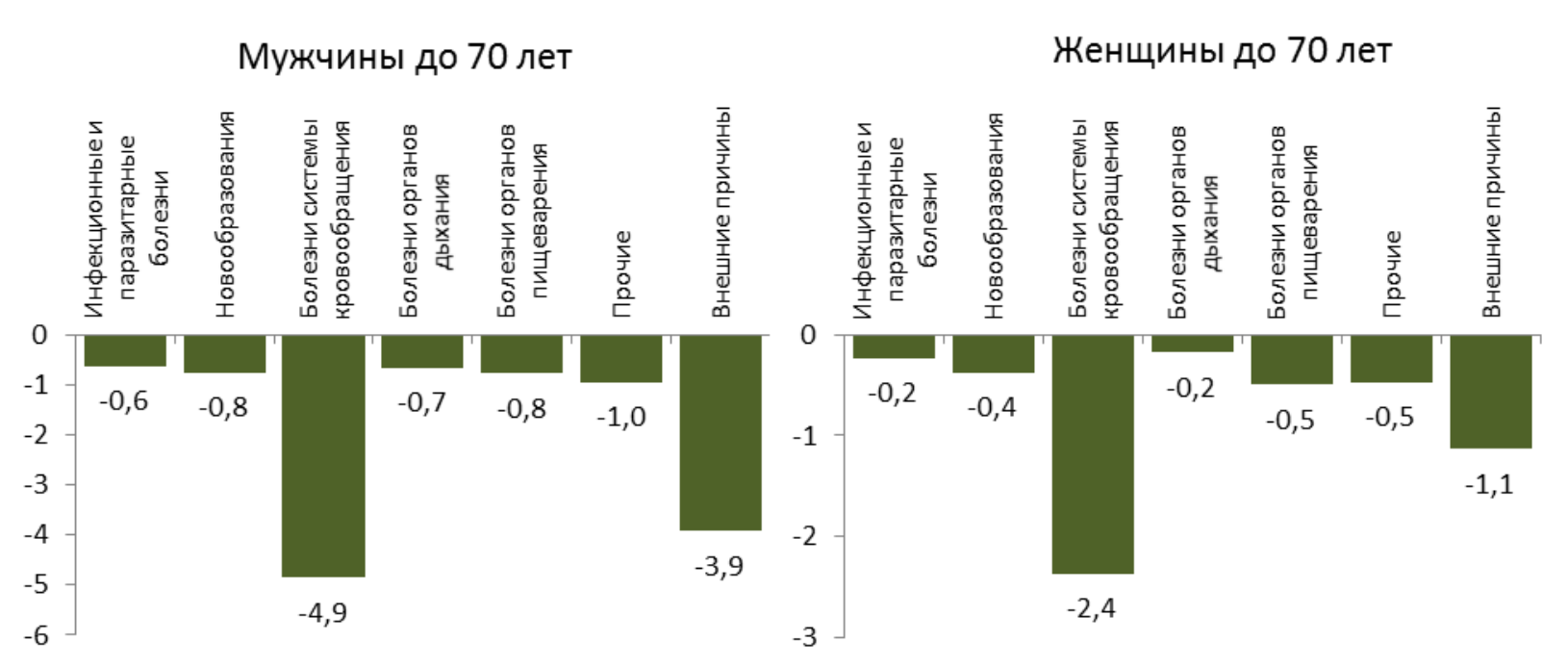

\section{Рисунок 16. Потери в ожидаемой продолжительности жизни в России в возрасте до 70 лет по сравнению со странами ЕС-15 в результате различий в смертности от крупных классов причин смерти, 2010, лет}

\section{ЗАКЛЮЧЕНИЕ}

Первая половина XX века в развитых странах ознаменовалась небывалым ростом ожидаемой продолжительности жизни. Несмотря на потрясения двух мировых войн, послевоенную разруху, экономические и социальные кризисы, продолжительность жизни в европейских странах, по которым имеются данные начиная с 1900 г., между началом века и 1960 г. и у мужчин, и у женщин выросла на 20-25 лет, иногда и больше (таблица 9). В России продолжительность жизни за это время удвоилась. Подобные перемены после тысячелетий стагнации продолжительности жизни человека даже в самых передовых странах своего времени иначе как революционными не назовешь.

На фоне этого скачка прирост продолжительности жизни в тех же странах за последующие полстолетия (между 1960 и 2010 г.) в лучшем случае на 10-12 лет, который ассоциируется со второй эпидемиологической революцией, выглядит не особенно большим. Но даже если использовать слово «революция» лишь как метафору и иметь в виду, что речь идет о продолжении начавшегося ранее движения, достижения последних 50 лет представляются весьма существенными. Они тем более значительны, что в 1950 -е 1960-е годы прирост продолжительности жизни во многих развитых странах замедлился, а то и вовсе приостановился, и тогда могло казаться, что возможности дальнейшего снижения смертности исчерпаны. Эти опасения не подтвердились. Вторая эпидемиологическая революция - пусть и не такого масштаба, как первая, - стала реальностью в большинстве промышленно развитых, урбанизированных стран.

Россия же, к сожалению, наблюдает эту революцию со стороны, не принимая в ней никакого участия. Вопрос о том, почему это происходит, выходит за рамки настоящей 
статьи. Нашей задачей было показать, в чем именно отставание России проявляется в терминах причин смерти; это необходимо понять, потому что без такого понимания нельзя выявить главные болевые точки и определить приоритеты стратегии борьбы за снижение смертности.

\section{Таблица 9. Прирост ожидаемой продолжительности жизни при рождении в} некоторых странах, лет

\begin{tabular}{l|ccc|c}
\hline \multirow{2}{*}{ Страна } & \multicolumn{2}{|c|}{ Мужчины } & \multicolumn{2}{c}{ Женщины } \\
\cline { 2 - 5 } & $1900-1960$ & $1960-2010$ & $1900-1960$ & $1960-2010$ \\
\hline Бельгия & 21,9 & 10,2 & 24,3 & 9,9 \\
Дания & 20,2 & 5,6 & 20,5 & 6,5 \\
Италия & 25,1 & 11,9 & 29,9 & 12,3 \\
Нидерланды & 24,4 & 7,1 & 25,5 & 7,5 \\
Норвегия & 19,6 & 7,5 & 20,7 & 7,5 \\
Финляндия & 25,1 & 11,3 & 29,2 & 11,2 \\
Франция & 23,8 & 10,5 & 26,8 & 10,7 \\
Швейцария & 22,5 & 10,7 & 25,3 & 10,0 \\
Швеция & 20,4 & 8,5 & 21,3 & 8,8 \\
Россия & 34,0 & $-0,3$ & 40,3 & 2,9 \\
\hline
\end{tabular}

Наш анализ показывает, что в России все еще сохраняется структура причин смерти кануна второй эпидемиологической революции, если и не во всех деталях, вникнуть в которые в рамках одной статьи невозможно, то в главных чертах. Не будет большим преувеличением утверждать, что преодоление отставания России от стран, уверенно идущих по пути этой революции, упирается, прежде всего, в нашу неспособность решить две ключевые проблемы: добиться значительного оттеснения к более поздним возрастам смертности от сердечно-сосудистых заболеваний и резко ограничить роль внешних причин смерти.

\section{БЛАГОДАРНОСТИ}

Автор благодарит Е.М. Андреева, С.А. Васина и Т.Л. Харькову за ценные советы и помощь в проведении расчетов.

\section{ЛИТЕРАТУРА}

Андреев Е.М. (1982). Метод компонент в анализе продолжительности жизни // Вестник статистики. № 9: 42-47.

Андреев Е.М., А.Г. Вишневский, К.Ю. Шабуров (1986). Продолжительность жизни и причины смерти // Демографические процессы и их закономерности / Под ред. А.Г. Волкова. М.: "Мысль": 110-130.

Вишневский А., В. Школьников, С. Васин (1991). Эпидемиологический переход и причины смерти в СССР // Экономика и математические методы. № 27 (6): 1013-1021.

Вишневский А., В. Школьников (1997). Смертность в России: главные группы риска и приоритеты действия. Научные доклады Московского Центра Карнеги. Вып.19: 83. 
Вишневский А. (2014). Демографическая революция меняет репродуктивную стратегию вида Homo sapiens // Демографическое обозрение № 1: 6-33.

Демографическая модернизация России, 1900-2000 (2006) / Под ред. А.Г. Вишневского. М.: Новое издательство: 601.

Вишневский А. (2009). Незавершенная демографическая модернизация в России // СПЕРО № 10: 55-82.

Омран А. (1977). Эпидемиологический аспект теории естественного движения населения // Проблемы народонаселения. О демографических проблемах стран Запада / Под ред. Д.И. Валентея и А.П. Судоплатова. М.: «Прогресс»: 57-91.

Семенова В.Г. (2005). Обратный эпидемиологический переход в России. М.: ЦСП: 235.

De Flora S., A. Quaglia, C. Bennicelli, and M. Vercelli (2005). The epidemiological revolution of the 20th century // The FASEB Journal 19: 892-897.

Editorials (1972).The epidemiologic revolution // American Journal of Public Health. 62 (11): 1439-1441.

Frenk J., J. L. Bobadilla, C. Stern, T. Frejka, and R. Lozano (1991). Elements for a theory of the health transition // Health Transition Review. 1 (1): 21-38.

Meslé F., J. Vallin (2002). La transition sanitaire : tendances et perspectives // Démographie : analyse et synthèse. Sous la direction de G. Caselli, J. Vallin et G. Wunsch. INRD. Volume III, Chapitre 57: 439-461.

Murray C.J.L., and A.D. Lopez, eds. (1996). The global burden of disease. A comprehensive assessment of mortality and disability from diseases, injuries, and risk factors in 1990 and projected to 2020. Summary: 43.

Olshansky S. J., and A. B. Ault (1986). The Fourth Stage of the Epidemiologic Transition: The Age of Delayed Degenerative Diseases // The Milbank Quarterly. 64 (3): 355-391.

Omran A. R. (1971). The epidemiologic transition: a theory of the epidemiology of population change // The Milbank Memorial Fund Quarterly. 49 (4): 509-538.

Omran A. R. (1998). The epidemiologic transition theory revisited thirty years later // World Health Statistics Quarterly. 51 (2-4): 99-119.

Terris M. (1976). The Epidemiologic Revolution, National Health Insurance and the Role of Health Departments. American Journal of Public Health. Vol. 66, № 12: 1155-1164.

WHO (2014). European Health for All database (HFA-DB). URL: http://www.euro.who.int/en/data-and-evidence/databases/european-health-for-all-databasehfa-db (дата обращения: 20.07.2014). 


\section{ПРИЛОЖЕНИЕ}

Таблица П-1. Избыточные табличные числа $\left(d_{x i}^{R}-d_{x i}^{E U-15}\right)$ мужских смертей в возрасте до 70 лет в России, по сравнению с ЕС-15, на 100000 мужчин, умирающих во всех возрастах и от всех причин, 1990

\begin{tabular}{|c|c|c|c|c|c|c|c|c|}
\hline Возраст х & 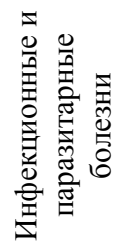 & 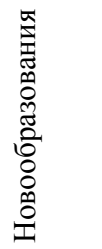 & 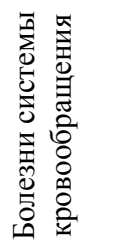 & 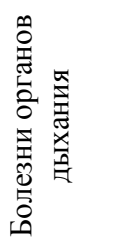 & 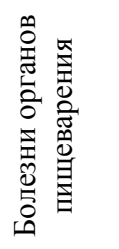 & 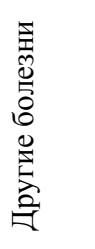 & 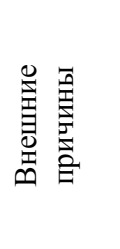 & 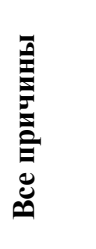 \\
\hline 0 & 126 & 5 & -2 & 244 & 7 & 672 & 48 & 1100 \\
\hline $1-4$ & 24 & 22 & -4 & 56 & 3 & 34 & 124 & 260 \\
\hline $5-9$ & 4 & 18 & -2 & 9 & 1 & 27 & 167 & 224 \\
\hline $10-14$ & 2 & 10 & -2 & 1 & 2 & 8 & 143 & 164 \\
\hline $15-19$ & 5 & 18 & 14 & 9 & 6 & 5 & 316 & 375 \\
\hline $20-24$ & 13 & 14 & 21 & 8 & 10 & -15 & 603 & 654 \\
\hline $25-29$ & 31 & 20 & 63 & 3 & 9 & -67 & 876 & 934 \\
\hline $30-34$ & 56 & 30 & 165 & 14 & 8 & -59 & 1064 & 1277 \\
\hline $35-39$ & 88 & 60 & 355 & 28 & 1 & -32 & 1118 & 1619 \\
\hline $40-44$ & 101 & 145 & 665 & 60 & 6 & 2 & 1116 & 2094 \\
\hline $45-49$ & 127 & 375 & 1107 & 143 & 2 & 9 & 1164 & 2928 \\
\hline $50-54$ & 129 & 526 & 1431 & 212 & -38 & -49 & 1005 & 3216 \\
\hline $55-59$ & 108 & 657 & 1781 & 345 & -90 & -133 & 767 & 3437 \\
\hline $60-64$ & 75 & 398 & 2234 & 378 & -92 & -245 & 488 & 3236 \\
\hline $65-70$ & 28 & -432 & 2030 & 226 & -126 & -466 & 209 & 1468 \\
\hline Всего & 916 & 1866 & 9856 & 1737 & -291 & -307 & 9209 & 22985 \\
\hline
\end{tabular}

\begin{tabular}{|l|l|l|l|l|l|r|}
\hline Число избыточных смертей: & Более 1000 & $500-1000$ & $\mathbf{3 0 0 - 5 0 0}$ & $\mathbf{1 0 0 - 3 0 0}$ & $\mathbf{5 0 - 1 0 0}$ & Менее 50 \\
\hline
\end{tabular}

Таблица П-2. Избыточные табличные числа $\left(d_{x i}^{R}-d_{x i}^{E U-15}\right)$ женских смертей в возрасте до 70 лет в России, по сравнению с ЕС-15, на 100000 женщин, умирающих во всех возрастах и от всех причин, 1990

\begin{tabular}{|c|c|c|c|c|c|c|c|c|}
\hline Возраст х & 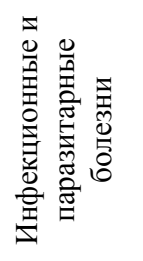 & 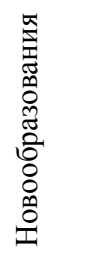 & 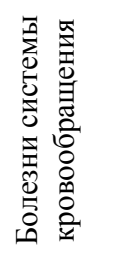 & 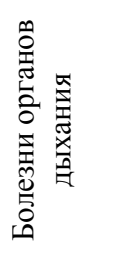 & 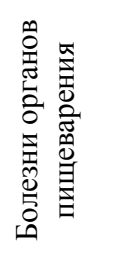 & 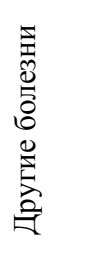 & 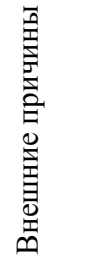 & 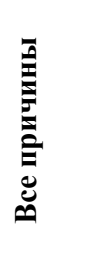 \\
\hline 0 & 110 & 7 & -1 & 189 & 3 & 419 & 41 & 766 \\
\hline $1-4$ & 21 & 17 & -5 & 45 & 2 & 37 & 84 & 202 \\
\hline $5-9$ & 1 & 14 & 0 & 5 & 0 & 20 & 56 & 96 \\
\hline $10-14$ & 1 & 10 & -3 & 3 & 2 & 10 & 35 & 58 \\
\hline $15-19$ & 2 & 13 & 6 & 4 & 4 & 28 & 96 & 153 \\
\hline $20-24$ & 8 & 19 & 11 & 5 & 7 & 28 & 80 & 158 \\
\hline $25-29$ & 8 & 25 & 14 & 3 & 2 & 8 & 92 & 152 \\
\hline $30-34$ & 8 & 34 & 27 & 4 & 0 & 20 & 125 & 218 \\
\hline $35-39$ & 12 & 37 & 55 & 8 & -5 & 32 & 162 & 300 \\
\hline $40-44$ & 11 & 78 & 149 & 13 & -6 & 34 & 193 & 472 \\
\hline $45-49$ & 10 & 100 & 322 & 27 & -12 & 42 & 241 & 730 \\
\hline $50-54$ & 8 & 63 & 570 & 33 & -8 & 28 & 230 & 924 \\
\hline $55-59$ & 6 & 29 & 1095 & 55 & 5 & 3 & 218 & 1411 \\
\hline $60-64$ & 0 & -23 & 1823 & 48 & 6 & -79 & 178 & 1954 \\
\hline $65-70$ & -14 & -176 & 2897 & 51 & 9 & -262 & 127 & 2632 \\
\hline Всего & 192 & 247 & 6961 & 492 & 10 & 367 & 1958 & 10227 \\
\hline
\end{tabular}

\begin{tabular}{|l|l|r|r|r|r|r|}
\hline Число избыточных смертей: & Более 1000 & $500-1000$ & $\mathbf{3 0 0 - 5 0 0}$ & $\mathbf{1 0 0 - 3 0 0}$ & $\mathbf{5 0 - 1 0 0}$ & Менее 50 \\
\hline
\end{tabular}


Таблица П-3. Избыточные табличные числа $\left(d_{x i}^{R}-d_{x i}^{E U-15}\right)$ мужских смертей в возрасте до 70 лет в России, по сравнению с ЕС-15, на 100000 мужчин, умирающих во всех возрастах и от всех причин, 2000

\begin{tabular}{|c|c|c|c|c|c|c|c|c|}
\hline Возраст х & 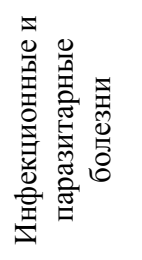 & 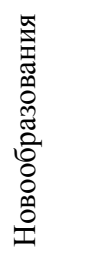 & 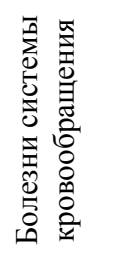 & 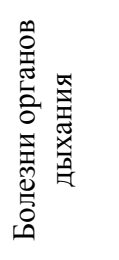 & 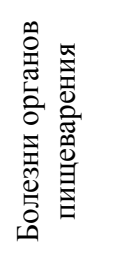 & 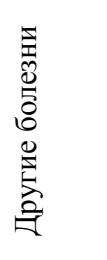 & 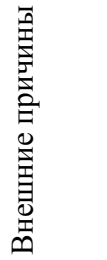 & 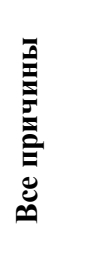 \\
\hline 0 & 92 & 6 & 2 & 170 & 5 & 811 & 91 & 1178 \\
\hline $1-4$ & 24 & 14 & 1 & 56 & 3 & 87 & 143 & 329 \\
\hline $5-9$ & 6 & 9 & 1 & 10 & 2 & 40 & 147 & 216 \\
\hline $10-14$ & 2 & 8 & 4 & 5 & 2 & 22 & 153 & 196 \\
\hline $15-19$ & 15 & 12 & 26 & 15 & 8 & 50 & 586 & 713 \\
\hline $20-24$ & 80 & 16 & 112 & 38 & 29 & 133 & 1471 & 1879 \\
\hline $25-29$ & 142 & 20 & 201 & 61 & 55 & 163 & 1644 & 2287 \\
\hline $30-34$ & 178 & 28 & 366 & 92 & 93 & 165 & 1682 & 2604 \\
\hline $35-39$ & 222 & 57 & 659 & 162 & 128 & 183 & 1784 & 3194 \\
\hline $40-44$ & 284 & 73 & 1148 & 238 & 147 & 227 & 1928 & 4044 \\
\hline $45-49$ & 309 & 158 & 1814 & 346 & 153 & 265 & 1967 & 5011 \\
\hline $50-54$ & 265 & 235 & 2571 & 426 & 161 & 278 & 1787 & 5722 \\
\hline $55-59$ & 204 & 291 & 3235 & 464 & 118 & 174 & 1459 & 5946 \\
\hline $60-64$ & 115 & -196 & 3753 & 427 & 9 & -28 & 959 & 5039 \\
\hline $65-70$ & 2 & -1191 & 3493 & 203 & -113 & -377 & 502 & 2518 \\
\hline Всего & 1940 & -460 & 17387 & 2712 & 800 & 2194 & 16303 & 40875 \\
\hline
\end{tabular}

\begin{tabular}{|l|l|l|l|l|l|r|}
\hline Число избыточных смертей: & Более 1000 & $500-1000$ & $300-500$ & $100-300$ & $50-100$ & Менее 50 \\
\hline
\end{tabular}

Таблица П-4. Избыточные табличные числа $\left(d_{x i}^{R}-d_{x i}^{E U-15}\right)$ женских смертей в возрасте до 70 лет в России, по сравнению с ЕС-15, на 100000 женщин, умирающих во всех возрастах и от всех причин, 2000

\begin{tabular}{|c|c|c|c|c|c|c|c|c|}
\hline Возраст x & 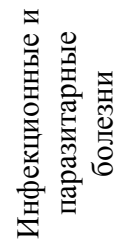 & 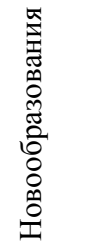 & 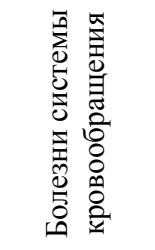 & 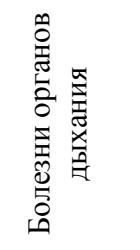 & 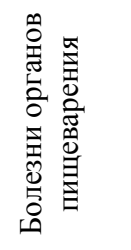 & 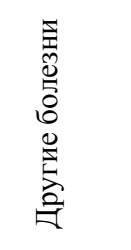 & 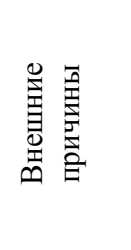 & 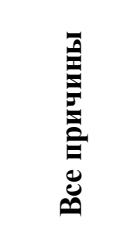 \\
\hline 0 & 66 & 6 & 4 & 135 & 6 & 578 & 78 & 873 \\
\hline $1-4$ & 19 & 15 & 1 & 57 & 2 & 68 & 100 & 263 \\
\hline $5-9$ & 4 & 7 & 4 & 9 & 2 & 27 & 66 & 118 \\
\hline $10-14$ & 2 & 6 & 0 & 3 & 1 & 15 & 59 & 87 \\
\hline $15-19$ & 8 & 13 & 11 & 7 & 4 & 32 & 182 & 256 \\
\hline $20-24$ & 22 & 17 & 23 & 13 & 9 & 53 & 257 & 394 \\
\hline $25-29$ & 30 & 27 & 45 & 18 & 21 & 60 & 280 & 482 \\
\hline $30-34$ & 33 & 48 & 91 & 28 & 28 & 67 & 303 & 597 \\
\hline $35-39$ & 32 & 60 & 157 & 35 & 37 & 73 & 342 & 737 \\
\hline $40-44$ & 41 & 73 & 298 & 47 & 54 & 75 & 389 & 975 \\
\hline $45-49$ & 38 & 106 & 572 & 66 & 65 & 97 & 449 & 1392 \\
\hline $50-54$ & 34 & 125 & 1057 & 67 & 96 & 126 & 498 & 2002 \\
\hline $55-59$ & 22 & 92 & 1863 & 60 & 146 & 139 & 495 & 2817 \\
\hline $60-64$ & -1 & -47 & 2767 & 28 & 100 & 52 & 366 & 3265 \\
\hline $65-70$ & -29 & -245 & 4546 & -38 & 61 & -127 & 285 & 4453 \\
\hline Всего & 320 & 301 & 11439 & 535 & 633 & 1335 & 4148 & 18711 \\
\hline Число избы & ных сл & & Более 1000 & $500-1000$ & $300-500$ & $100-300$ & $50-100$ & Менее 50 \\
\hline
\end{tabular}




\section{MORTALITY IN RUSSIA: THE SECOND EPIDEMIOLOGIC REVOLUTION THAT NEVER WAS*}

ANATOLY VISHNEVSKY

ANATOly G. VishVEVSKy. Institute of Demography, National RESEARCh University Higher School OF Economics. E-MAIL: avishnevsky@hse.ru. DATE RECEIVED: August 2014.

The article looks at different approaches (the "new phase" of the epidemiologic transition, "the second epidemiologic revolution", a "health transition") to conceptualization of the present stage of mortality reduction, in which noncommunicable diseases and causes of death resulting from external sources come to the fore. At this stage, which has lasted for at least half a century, revolutionary changes have taken place in most developed countries. These changes manifest themselves in the drastic expansion of control over noninfectious causes of death, particularly over diseases of the circulatory system, neoplasms, and other noncommunicable diseases, as well as over external causes of death. The consequence of these changes has been the rapid shift of deaths from the abovementioned causes to older ages, an increase in the mean age of death from them and, ultimately, a significant rise in life expectancy. Meanwhile, Russia has been mostly unaffected by these changes and has failed to provide the necessary growth of control over noncommunicable causes of death. The age distribution of deaths from major classes of causes of death in Russia over the past half-century has not changed, leading to a stagnation in life expectancy and to an increasing lag behind the majority of developed countries with respect to this indicator. "The second epidemiologic revolution" in Russia is still a matter for the future.

Key words: epidemiologic transition, epidemiologic revolution, second epidemiologic revolution, health transition, causes of death, noncommunicable diseases, injuries.

* The STUdy Was implemented in the fRAmework of the Basic Research Program at the National ReSEARCh University HigHER SCHOOL OF ECONOMICS (HSE) IN 2013-2014.

\section{REFERENCES}

Andreev E.M. (1982). Metod komponent v analize prodolzhitel'nosti zhizni [Component method in the analysis of life expectancy] // Vestnik statistiki [Bulletin of statistics]. № 9: 42-47.

Andreev E.M., A.G. Vishnevsky, K.Yu. Shaburov (1986). Prodolzhitel'nost' zhizni i prichiny smerti [Life expectancy and causes of death] // A.G. Volkov, ed. Demograficheskiye protsessy i ikh zakonomernosti [Demographic processes and their regularities] M.: "Mysl'": $110-130$.

De Flora S., A. Quaglia, C. Bennicelli, and M. Vercelli (2005). The epidemiological revolution of the 20th century // The FASEB Journal 19: 892-897.

Demograficheskaya modernizatsiya Rossii, 1900-2000 [Demographic modernisation of Russia, 1900-2000] (2006) / A.G. Vishnevsky, ed. M.: Novoye izdatel'stvo.

Editorials (1972). The epidemiologic revolution // American Journal of Public Health. 62 (11): 1439-1441.

Frenk J., J. L. Bobadilla, C. Stern, T. Frejka, and R. Lozano (1991). Elements for a theory of the health transition // Health Transition Review. 1 (1) : 21-38.

Meslé F., J. Vallin (2002). La transition sanitaire : tendances et perspectives // Démographie : analyse et synthèse. Sous la direction de G. Caselli, J. Vallin et G. Wunsch. INRD. Volume III, Chapitre 57: 439-461. 
Murray C.J.L., and A.D. Lopez, eds. (1996). The global burden of disease. A comprehensive assessment of mortality and disability from diseases, injuries, and risk factors in 1990 and projected to 2020. Summary: 43.

Olshansky S. J., and A. B. Ault (1986). The Fourth Stage of the Epidemiologic Transition: The Age of Delayed Degenerative Diseases // The Milbank Quarterly. 64 (3): 355-391.

Omran A. R. (1971). The epidemiologic transition: a theory of the epidemiology of population change // The Milbank Memorial Fund Quarterly. 49 (4): 509-538.

Omran A.R. (1977). Epidemiologicheskiy aspekt teorii yestestvennogo dvizheniya naseleniya [Epidemiological aspects of the theory of natural movement of the population] // D.I. Valentey, A.P. Sudoplatov, eds. Problemy narodonaseleniya. O demograficheskikh problemakh stran Zapada [Population Problems. On the demographic problems of the West]. Moskva: Progress: 57-91.

Omran A. R. (1998). The epidemiologic transition theory revisited thirty years later // World Health Statistics Quarterly. 51 (2-4): 99-119.

Semenova V.G. (2005). Obratnyy epidemiologicheskiy perekhod v Rossii [Reverse epidemiological transition in Russia]. M.: TsSP.

Terris M. (1976). The Epidemiologic Revolution, National Health Insurance and the Role of Health Departments. American Journal of Public Health. Vol. 66, № 12: 1155-1164.

Vishnevsky A., V. Shkolnikov, S. Vassin (1991). Epidemiologicheskiy perekhod i prichiny smerti v SSSR [Epidemiologic transition and causes of death in the USSR] // Ekonomika i matematicheskiye metody [Economics and Mathematical Methods]. № 27 (6): 1013-1021.

Vishnevsky A., V. Shkolnikov (1997). Smertnost' v Rossii: glavnyye gruppy riska i prioritety deystviya [Mortality in Russia: main risk groups and priorities of action]. Nauchnyye doklady Moskovskogo Tsentra Karnegi [Scientific reports of the Carnegie Moscow Center]. Vyp.19: 83.

Vishnevsky A. (2009). Nezavershennaya demograficheskaya modernizatsiya v Rossii [Incomplete demographivc modernisation of Russia] // SPERO № 10: 55-82.

Vishnevsky A. (2014). Demograficheskaya revolyutsiya menyayet reproduktivnuyu strategiyu vida Homo sapiens [The demographic revolution is changing the reproductive strategy of Homo sapiens] // Demograficheskoye obozreniye [Demographic Review] № 1: 6-33.

WHO (2014). European Health for All database (HFA-DB). URL: http://www.euro.who.int/en/data-and-evidence/databases/european-health-for-all-databasehfa-db (data accessed: 20.07.2014). 